SJ Quinney College of Law, University of Utah Utah Law Digital Commons

Utah Law Faculty Scholarship

Utah Law Scholarship

$6-2018$

\title{
Needles, Haystacks, and Next-Generation Genetic Sequencing
}

Teneille R. Brown

S.J. Quinney College of Law, University of Utah, teneille.brown@law.utah.edu

Follow this and additional works at: https://dc.law.utah.edu/scholarship

Part of the Health Law and Policy Commons

\section{Recommended Citation}

Brown, Teneille R., "Needles, Haystacks, and Next-Generation Genetic Sequencing" (2018). Utah Law Faculty Scholarship. 108. https://dc.law.utah.edu/scholarship/108

This Article is brought to you for free and open access by the Utah Law Scholarship at Utah Law Digital Commons. It has been accepted for inclusion in Utah Law Faculty Scholarship by an authorized administrator of Utah Law Digital Commons. For more information, please contact valeri.craigle@law.utah.edu. 


\title{
Needles, Haystacks and NeXt-Generation Genetic Sequencing
}

\author{
Teneille R. Brown ${ }^{1}$
}

\begin{abstract}
:
Genetic testing is becoming more frequent and the results more complex. Not infrequently, genetic testing conducted for one purpose reveals information about other features of the genome that may be of clinical significance. These unintended findings have been referred to as "incidental" or "secondary" findings. In 2013, the American College of Medical Genetics ("ACMG") recommended that clinical laboratories inform people if their genetic analyses indicate that they have certain secondary mutations. These mutations were selected because they probably cause a serious disease, which is treatable, and may go undetected. The ACMG's recommendations galvanized critical responses by the genetics and ethics community. One of the most important open questions concerns the scope of negligence liability for clinical laboratories if they failed to provide any of these SFs to patients who never requested them. To answer this question, this article argues that while there might be an ethical or professional obligation to share knowledge about these specific genetic mutations, laboratories should not be subject to tort liability for failure to share secondary findings directly with patients.
\end{abstract}

\footnotetext{
${ }^{1}$ Teneille R. Brown, J.D. is a Professor of Law at the University of Utah, S.J Quinney College of Law, and an adjunct Professor of Internal Medicine in the Division of Medical Ethics and Humanities at the University of Utah. Research reported in this publication was supported by Utah Center for Excellence in ELSI Research (UCEER). UCEER is supported by the National Human Genome Research Institute of the National Institutes of Health under Award Number P20HG007249. The content is solely the responsibility of the authors and does not necessarily represent the official views of the National Institutes of Health.
} 
Gone are the days of treating patients based upon their symptoms alone. Instead, in a growing number of contexts, physicians prescribe treatments based on an individual's unique genetic information, ("genotype."). 2 This is the essence of precision medicine: a bold new frontier of innovation in health care where treatments are no longer "one size fits all." It is already standardof-care for oncologists to order a genetic test to determine which chemotherapy to use to treat small-cell lung cancer.3 If the tumor possesses epidermal growth factor receptor ("EGFR") genetic mutations the cancer is more likely to respond to a chemotherapy drug called Tarceva ${ }^{\circledR} .4$ It is also common to perform a genetic test for Human leukocyte antigen before prescribing abacavir, an HIV drug, as certain mutations predict adverse reactions including death.5 The potential to improve treatments using genetic information is enormous. Looking for the next genetic discovery to more precisely treat cancers and other life-threatening diseases has resulted in a great deal of clinical research relating to genetic samples. 6

Up until recently, genetic tests were mostly used to confirm the diagnosis of disease rather than to guide personalized treatments. Traditional genetic tests looked for the presence or absence of mutational "hotspots".7 Often doctors needed to know what he/she was looking for, and roughly where it was in the genome, and the test would tell you whether the disease-causing mutation was present. This is how genetic tests for Sickle Cell, Cystic Fibrosis, and many other common genetic diseases have worked for decades. 8

2 In contrast, treatment based on "phenotype" or the way a patient's symptoms manifest, has been the traditional, bread and butter of medicine. See generally PERSONALIZED MEdicine CoAlition, THE CASE FOR PERSONALIZED MEDICINE, 42 (4th ed. 2014).

3 Lung Cancer Genomic Testing (EGFR, KRAS, ALK), MEMORIAL SloAn KeTtering CANCER CTR., https://www.mskcc.org/cancer-care/types/lung/diagnosis/genetic-testing (last accessed Nov. 9, 2017); What's New in Non-Small Cell Lung Cancer, AM. CANCER SOCIETY, https://www.mskcc.org/cancercare/types/lung/diagnosis/genetic-testing (last updated May 16, 2016); see generally Federico Innocenti, Nancy J Cox \& M. Eileen Dolan, Use of Genomic Information to Optimize Cancer Chemotherapy 38 SEMIN. ONCOLOGY 186 (2012).

4 Yongsheng Wang, Gerlad Schimd-Bindert, \& Caicun Zhou, Erlotinib in the Treatment of Advanced Non-Small Cell Lung Cancer: an Update for Clinicians, 4 THERAPEUTIC ADVANCES IN MED. ONCOLOGY 19, 26 (2011).

5 Ana Alfirevic and Munir Pirmohamed, Genomics of Adverse Drug Reactions, 38 TRENDS IN PHARMACOLOGICAL SCIENCES 100, 101-102 (2017)[hereinafter Alfirevic].

6 ClinicallTrials.gov., U.S. NAT'L LIBRARY OF MED., https://clinicaltrials.gov (last visited Feb. 24, 2018)( search "genetic samples" under "other terms" field).

7 Sara Huston Katsanis \& Nicholas Katsanis, Molecular Genetic Testing and the Future of Clinical Genomics, 14 NATURE REV. GENETICS 415, 417 (2013) and see GENEWIZ,

https://www.genewiz.com/en/Public/Services/Next-Generation-Sequencing/Targeted-ResequencingPanels/Cancer-Panels/Hot-Spot-Cancer-Panels (last visited Mar. 15, 2018) ("Hotspot cancer panels target regions of known cancer genes that have been well-characterized as mutational hotspots.").

8 Id.; Philippa Brice, James Jarrett, \& Miranda Mugford, Genetic Screening for Cystic Fibrosis: An Overview of the Science and the Economics 6 J. CYSTIC FIBROSIS 255, 256 (2007). 
This all changed with the advent of next-generation genetic sequencing. One no longer needs to have a needle in mind. Tests can now search the entire haystack to see if there is anything of interest anywhere. While much is lost in resolution and validity, much is gained in scope. Socalled "next generation whole genome sequencing," or simply "WGS" can decode three billion base pairs or the complete DNA sequence of an organism's genome with one tissue or blood sample.9 Sequencing a genome used to be done manually, but the process has become more automated and therefore much faster, thus being labeled the "next generation." 10 In humans, this means that the chromosomal, and mitochondrial DNA, may be rapidly sequenced.11 When WGS first hit the scene, the process was prohibitively expensive so it was only used in well-funded laboratories as demonstration projects. But that is no longer the case. The price has dropped to about $\$ 1500$ per sample, so WGS is more commonly used in clinical research and treatment.12 But it is not yet standard-of-care because insurance usually does not covered it.13 WGS takes longer than other methods and yields a complex range of tricky-to-interpret results. Such results vary from those that predict risk for simple Mendelian diseases - caused by single genes - to those that implicate common, risk alleles with small effect sizes for multi-gene traits (caused by multiple genes). 14

Rather than employing expensive WGS, more clinicians use whole-exome sequencing as a cheaper and faster alternative. 15 Whole exome sequencing ("WES") sequences only exons: the portions of a person's genome that code for proteins or peptides. 16 The exons represent only two percent of the genome but account for roughly eighty-five percent of the mutations that increase the risk of disease 17 Clinical use of WES is rising in two contexts: cancer research 18 and assisting

9 Next Generation Sequencing, GENEwIZ, https://www.genewiz.com/en/Public/Resources/SampleSubmission-Guidelines/Next-Generation-Sequencing-Sample-Submission-Guidelines (last visited Nov. 9, 2017).

10 Sam Behjati and Patrick S. Tarpey, What is Next Generation Sequencing?, 98 ARCH. DIS. CHILD EDUC. PRACT. ED. 236, 236 (2013).

11 See Carla Van El, et al., Whole-Genome Sequencing in Health Care: Recommendations of the European Society of Human Genetics, 21 EURO. J. HUM. GENET. 580, 582 (2013).

12 See How it Works, SCIENCE EXCHANGE, https://www.scienceexchange.com/services/whole-genomeseq (last visited June 28, 2017).

13 Cigna Issues Coverage Criteria for Whole-Exome Sequencing; WGS Still Not Covered, GENOMEWeB (Nov. 23, 2015), https://www.genomeweb.com/sequencing-technology/cigna-issues-coverage-criteriawhole-exome-sequencing-wgs-still-not-covered [hereinafter GenomeWeb]; The Cost of Sequencing a Human Genome, NAT'L. HUMAN GENOME RES. INST., https://www.genome.gov/275651098/the-cost-ofsequencing-a-human-genome/ (last updated July 6, 2016).

14 Jason Vassy, et al., The Impact of Whole-Genome Sequencing on the Primary Care and Outcomes of Healthy Adult Patients, 167 ANN. INTERNAL MED. 159, 159 (2017) [hereinafter Vassy]. 15 GENOMEWEB, supra note 12.

16 Lauren Westerfield, The Use of Whole Exome Sequencing to Detect Novel Genetic Disorders: Two Cases and an Assessment of the Technology, 2 (2013)(dissertation, University of Pittsburgh).

17 Julie Steenhuysen, As sequencing moves into clinical use, insurers balk, REUTERS (June 19, 2014), http://www.reuters.com/article/us-health-sequencing-insight-idUSKBN0EU16S20140619.

18 WES is more common in cancer research, such as The Cancer Genome Atlas (TCGA), Stand Up To Cancer (SU2C) and other studies seeking to discover genotypes associated with particular tumors. Hanna Rennert, et al., Development and validation of a whole-exome sequencing test for simultaneous detection of point mutations, indels and copy-number alterations for precision cancer care, 1 GENOMIC MED. 16019,16019 (2016). 
patients on diagnostic odysseys.19 If the laboratory finds something interesting through WGS or WES, laboratories can, and should, confirm whether the result is a false positive or false negative through a more validated, targeted genetic test.20

These next-generation genetic analyses present novel questions for ordering physicians and laboratories.21 Because physicians do not need to know what to look for before using WGS or WES, physicians can cast a wide net. Before, if a child presented symptoms of cystic fibrosis (CF), the physician ordered a specific genetic test to confirm whether the CF mutation was present. The laboratory took a blood sample, ran the cystic-fibrosis test, and confirmed the results.22 But nowwith one blood sample - the clinical laboratory can scan an genome or exome looking for thousands of other mutations.23 Maybe the symptoms are caused by something the physician never considered? Maybe there is an interesting mutation, but its presence is too rare to say it's disease-causing?

WGS or WES invite a huge data dump. This data dump can come in various forms, depending on the way the lab reports its data. It can include preliminary information on many diseases for which the patient shows no symptoms and which were not related to the reason the physician ordered the test.24 Instead of hearing that a child does or does not have cystic fibrosis, a parent might also learn that the child is at risk for developing early-onset Alzheimer's or colon cancer. These additional mutations are called "secondary findings," because they are discovered incidentally to the primary target of the test. 25 While secondary findings are possible with all types

19 S.L. Sawyer., Utility of Whole- exome Sequencing for Those near the End of the Diagnostic Odyssey: Time to Address Gaps in Care, Clinical Genetics, 89 Clin. GeNET. 275, 275-284, 279 (2016) (The study, using WES had a higher diagnostic rate for Ciliopathy, metabolic and neurodevelopmental disorders, and dysmorphic syndromes.).

20 Rachel L. Goldfeder, et al., Medical Implications of Technical Accuracy in Genome Sequencing, 8 GENOME MED. 9 (2016).

21 For purposes of this paper, I am restricting my analysis to labs that are subject to the Clinical Laboratory Improvement Amendments of 1988 (CLIA) as they are clinical labs that examine "materials derived from the human body for the purpose of providing information for the diagnosis, prevention, or treatment of any disease or impairment of, or the assessment of the health of, human beings." see 42 U.S.C. $§ 263 \mathrm{a}$ (2017).

22 Carrier Testing for Cystic Fibrosis, Cystic FiBrosis Found., https://www.cff.org/What-is-

$\mathrm{CF} /$ Testing/Carrier-Testing-for-Cystic-Fibrosis/ (last visited Mar. 1, 2018).

23 Clinical Whole Exome Sequencing Information and FAQ, N.Y. GENOME CTR.,

http://www.nygenome.org/wp-content/uploads/2016/05/NYGC-Clinical-Whole-Exome-Sequencing.pdf,

12 (last updated Jan27, 2016).

$24 \mathrm{Id}$. at 7.

25 Secondary findings are not new to medicine. Analogous scenarios have developed in radiology and pathology, where clinicians discovered tumors and disease that were adjacent to the region of primary interest. Clinical Sequencing Exploratory Research, Medically Actionable or Secondary or Incidental Results, AM. SOC'Y OF HUM. GENETICS,

https://www.ashg.org/education/csertoolkit/medicallyactionable.html (last visited Mar. 1, 2018).See also Robert C. Green et al., ACMG Recommendations for Reporting of Incidental Findings in Clinical Exam and Genome Sequencing, 15 GenETICS IN MED. 565, 568 (2013) ("In clinical exome and genome sequencing, there is potential for the recognition and reporting of incidental or secondary findings unrelated to the indication for ordering the sequencing but of medical value for patient care."). Whether 
of genetic testing, they are significantly more likely with WES and WGS due to the volume of data analyzed.26

This article addresses whether the tort law of negligence imposes any obligation on the laboratory to disclose genetic-risk information secondary to the primary reason for ordering the test, a "secondary finding" or (SF).27 Whether there is a legal duty to warn is a threshold question for the judge to apply to similar future cases. Thus, before answering case-specific questions about whether there is a breach of the standard of care or whether the breach actually and proximately caused the patient's injury, there must exist a duty. This article will proceed in two parts. First, it introduces the topic and the professional obligations imposed by the American College of Medical Genetics. ("ACMG"). Second, it discusses the common-law factors courts routinely use when deciding whether to impose an affirmative duty to warn. The article argues against imposing this kind of duty on clinical laboratories.

\section{Much DePENDS ON How The COMPLAINT IS Framed}

Whether a judge will find that the laboratory has a particular duty will depend a great deal on how the patient frames his or her complaint. What sort of duty is being alleged? Is the plaintiff arguing that the defendant acted carelessly, or that the defendant did not act at all? These distinctions matter a great deal and make it impossible to answer the question of liability in the abstract. The outcome also depends on whether the plaintiff has brought a wrongful-death claim or a "lost chance" claim, for the loss of a better clinical outcome, because a medical diagnosis was delayed. Courts treat each type of negligence differently depending on the alleged duty and injury. Because this article seeks to provide practical, concrete guidance to judges, it will address a particular question: whether a laboratory should have disclosed a mutation directly to the patient. While some fact-specific questions arise in this context, a proper analysis of duty should proceed more in-abstractly, without wading too deep in the particulars of any case.

This article envisions one a very narrow type of duty-to-warn claim where the patient sues the laboratory for not providing SFs to the patient, and as a result, the patient failed to pursue a clinical intervention that they would have otherwise taken had they known of the genetic risk. If the laboratory returns some SFs to the plaintiff, but does so resulting in substandard information about the clinical significance of those findings, then this event might be framed as a more traditional negligence claim and the operative question will be whether the lab breached the duty by falling below the standard of care. The defendant acted in disclosing the SF, but just did not act appropriately.

\footnotetext{
laboratories should be held to the same standard as radiologists or pathologists will be covered later in the article. Infra

26 Madhuri Hegde, et al, Reporting Incidental Findings in Genomic Scale Clinical Sequencing - a Clinical Laboratory Perspective, 17 J. MOLECULAR DIAG. 107, 109-10 (2015).

27 The ensuing factors and analysis could be applied to a mutation of uncertain present clinical value, "dubbed a variant of unknown significance" or (VUS), but this will not be the focus of this paper. This article relates to the question of imposing a tort duty to disclose the results, and the analysis of returning VUS hinges more on the analysis of breach, and whether return of these types of results falls below the standard of care for laboratories.
} 
In any negligence action, the plaintiff states in her complaint what exactly the breach of the duty was and how performance of this duty would have prevented the injury for which she seeks compensation. She must prove each of four elements - duty, breach, causation, and injury to prevail. 28 In some cases, a duty to contact or warn might be imposed because it requires little of defendants.29 In the context of genetic sequencing, a plaintiff might allege that the lab has a duty to send all genetic-testing results, including those from exome sequencing, to the ordering provider. But if imposing this duty is unlikely to prevent the harm the plaintiff suffered from a delayed diagnosis - because, for example, there is evidence that the physician would not understand or use the information to change the patient's treatment in a way that would have prevented her injury - then a breach of this duty cannot have caused plaintiff's harm.30 Each of the elements of a negligence claim must align with one another, such that the duty imposed, if performed up to the standard of care, would have likely prevented the particular injury alleged. 31

\section{The AMERICAN COllege of Medical Genetics RePORT}

As soon as the inevitability of SFs emerged with next-generation sequencing, scholars began asking what obligations physicians, laboratories, and researchers might have to report these findings to patients and their relatives. 32 Researchers have suggested that there might be ethicaland perhaps legal - duties to warn patients of particular mutations, specifically if the mutations are known to be disease-causing ("pathogenic"), are quite likely to develop ("highly penetrant"), and there exist effective treatments available ("clinically actionable"). While amendments to the HIPAA Privacy Rule clarified that research subjects can request raw sequencing research results from CLIA-certified clinical laboratories, 33 the question remains about whether the labs might have an affirmative obligation to provide SFs to patients, or research subjects, who never affirmatively requested them.

28 See Blue Ridge Service Corp of VA v. Saxon Shoes, 624 S.E.2d 55, 62 (Va. 2006).

29 Peter M. Gerhart, Tort LaW AND Social Morality, 133-134 (2000).

30 Assuming there is a duty, to see how causation operates in these types of cases, see, Kaffka v. N.Y. Hosp., 228 A.D.2d 332, 333 (1996) ("Expert testimony that Dr. Minick delayed diagnosis of cancer does not establish causation when uncontested evidence shows that, by the time of his examination, Mrs. Kaffka's cancer had already metastasized to the bone and liver, tragically sealing her fate.").

31 See Robert F. Schopp and Michael R. Quattrocchi, Tarasoff, the Doctrine of Special Relationship, and the Psychotherapist's Duty to Warn, 12 J. PSYCHIATRY \& L.13, 16 (1984).

32 See Catherine Gliwa and Ben Berkman, Do Researchers Have an Obligation to Actively Look for Genetic Incidental Findings?, 13 AM. J. BIOETHICs 32, 35-36 (2013); see

Holly Tabor, et al., Genomics Really Gets Personal: How Exome and Whole Genome Sequencing Challenge the Ethical Framework of Human Genetics Research, 155 AM. J. MED. GENETICS 2916, 2924 (2011); see Wylie Burke, et al., Recommendations for returning genomic incidental findings? We need to talk!, 15 GENETICS IN MED. 854, 854-57(2013); Joon-Ho Yu, et al., Attitudes of Genetics Professionals Toward the Return of Incidental Results from Exome and Whole-Genome Sequencing, 95 AM. J. HUMAN GENETICS 77, 84 (2014) [hereinafter Yu 2014]; Susan M. Wolf, Jordan Paradise, and Charlisse Cagaanan, The Law of Incidental Findings in Human Subjects Research, 36 J. L., MED. \& ETHICS 361, 362-63, 365 (2008).

3345 C.F.R. $\$ 493.1291$ (2016). HHS’s amendments to the Health Insurance Portability and Accountability Act of 1996 ("HIPAA") Privacy Rule and the Clinical Laboratory Improvement Amendments of 1988 (CLIA) regulations require laboratories in HIPAA covered entities that process research results to provide the results to research subjects upon request. 
In 2013, a working group of the ACMG published a much-anticipated list of fifty-six SFs that clinical diagnostic laboratories performing exome or genome sequencing should report to patients.34 The working group - comprised of sixteen clinical lab directors and respected geneticists - explicitly avoided making legal recommendations and instead emphasized that the guidance was meant as an "educational resource for medical geneticists and other health care providers to help them provide quality medical genetic services." 35 Professional guidelines can inform legal standards, and so this report renewed interest in whether there might also be tort liability for failure to provide certain SFs to patients. While the initial ACMG report recommended disclosing SFs even when the DNA samples came from children36 and where the patients expressed no interest in learning this information, the initial recommendations suggested reporting SFs even to patients who did not request them, the ACMG later changed the recommendation to permit patients to opt out of being given their results. 37

The working group focused on the low-hanging fruit.38 Quite sensibly, it limited its recommendation to the mutations that were simplest to interpret and classify: single-gene mutations known to increase the risk of developing serious disease.39 It deferred answering whether there might be an obligation to return results that are less predictable and more ambiguous. In addition to being amenable to preventative clinical measures or treatment, other factors weighed in favor of disclosure in the ACMG report, for example, that: the mutations were: highly penetrant, known to be pathogenic, verifiable by other diagnostic methods, somewhat more common than other monogenic disorders, and had clinical presentations that meant they otherwise might escape detection for long periods of time. 40

Applying these criteria, based on clinical guidance and some emerging data, the working group initially decided that fifty-six SFs should be disclosed. The report acknowledged that the list should be curated as we gather more population and risk data.41 Specifically, the list will

34 See Green RC, et al., American College of Medical Genetics and Genomics. ACMG recommendations for reporting of incidental findings in clinical exome and genome sequencing. 15 GENET MED 565, 570 (2013) [hereinafter Green].

35 See $i d$.

36 One thing that the ACMG recommendations got right from a tort duty perspective is that legally it makes no difference whether the samples came from kids or adults. If the risk of harm from not disclosing is foreseeable, then the lab would have a duty that would extend to children. See Foreseeable Law and Legal Definition, USLEGAL, https://definitions.uslegal.com/f/foreseeable/ (last visited Nov. 26, 2017). 37 Green, supra note 32 , at 569.

380ne thing that the ACMG recommendations got right from a tort duty perspective is that legally it makes no difference whether the samples came from kids or adults. If the risk of harm from not disclosing is foreseeable, then the lab would have a duty that would extend to children. See Foreseeable Law and Legal Definition, USLEGAL, https://definitions.uslegal.com/f/foreseeable/ (last visited Nov. 26, 2017). 39 Green, supra note 32, at 569.

40 The ACMG working group did not recommend reporting variants of unknown significance (VUS), as they "recognized the challenge of attempting to report and interpret variants of unknown significance as incidental findings." See id.

41 See Sarah Kalia, et al., Recommendations for reporting of secondary findings in clinical exome and genome sequencing, 2016 update (ACMG SF v2.0): a policy statement of the American College of Medical Genetics and Genomics, 19 Genetics in Medicine 249, 253-54 (2017) [hereinafter Kalia]. ("We 
change as we gain information on genetic "penetrance," or the percentage of people who have a gene variant who go on to express or develop the associated disease.42 Much of the data upon which the ACMG recommendations were based relied on case reports where the individual was already symptomatic (e.g., the disorder was already present in the individual).43 When laboratories start providing SFs on samples that were tested primarily for something else, and for individuals who had not yet developed any symptoms of the SF-linked disease, then it is expected that penetrance will be much lower, and many of the people who test positive for the mutation will never go on to develop the disease (or, "phenotype").44 Because high penetrance was a key factor leading the ACMG to include a particular mutation on its list, the ACMG might need to remove mutations from the list where the likelihood of an asymptomatic person developing the disease is quite low.

Not surprisingly given the rapid pace of genetic discovery, just three years after its publication, the original 2013 report has already been amended.45 This second report has been referred to as "ACMG SF v2.0" and added another criterion for disclosure of SFs: acceptability of

anticipate that the increasing availability of large population databases, such as the Exome Aggregation Consortium (ExAC), will be helpful in refining estimates of penetrance, which may inform future curation of the ACMG SF v2.0 list"... incorporation of pharmacogenomic (PGx) variants onto a SF minimum list has also been considered [but rejected]... due to a lack of randomized, controlled trials and small numbers of patients for whom PGx results are available.").

42 As some of the data supporting foreseeability of harm relied on case reports where the phenotype was already present in the individual, it's possible that penetrance might be lower in individuals whose samples were tested primarily for something else (and who had not yet developed the disease). Put differently, there might be high false positives for individuals with some of these mutations who will never develop the related diseases. See LORI B. ANDREWS ET AL., ASSESSING GENETIC RISKS: IMPLICATIONS FOR HEALTH AND SOCIAL POLICY, 39 (National Academy Press, 1994). 43 Joel Zlotogora, Penetrance and Expressivity and in the Molecular Age, 5 GENETIC MED. 347, 252 (2003).

44 David Cooper, et al., Where genotype is not predictive of phenotype: towards an understanding of the molecular basis of reduced penetrance in human inherited disease, 132 Human Genetics 1077, 1081 (2013) "It is not hard to see why reduced penetrance might be much more common among described mutations than originally thought: whereas known pathological mutations have almost invariably been identified through retrospective analyses of families or well-defined groups of clinically symptomatic patients, relatively few prospective studies of asymptomatic carriers have so far been performed to derive estimates of penetrance."

45Based on feedback the initial report received, the ACMG solicited revisions to the original 2013 list and reviewed those proposals. ACMG then issued another statement in 2016 where they recommended reporting an additional set of mutations, (and removing one that had previously been recommended). The mutation that was removed from the recommended list was MYLK, which is associated with familial thoracic aortic aneurysm and dissection (FTAAD). It was removed after the ACMG SF 2.0 working group assessed the rarity of its pathogenic variants, the inability to effectively confirm it through diagnostic testing, and the lack of data on how effective medications are on reducing stress on the aorta. See, Sarah Kalia, supra note 39, at250-51. 
the proposed clinical intervention based on its risks and benefits.46 The working group stated that additional genes may be analyzed and reported if the lab deems it appropriate. 47

The ACMG working group justified their recommendations because laboratory personnel have a "fiduciary duty to prevent harm by warning patients and their families about certain incidental findings and that this principle supersedes concerns about autonomy."48 Fiduciary duties stem from agency principles, as the agent is often stepping in the shoes of the principal and should therefore assert the latter's best interests in a loyal and honest way.49 While it makes sense to impose fiduciary obligations on physicians and health care providers, it is not obvious that the lab sits in such a position to the patient. In any event, it is a confusing twist to use fiduciary principles to potentially thwart an individual's right to autonomy and provide information to them that they might not desire.50 Given that the ACMG report did expect that the lab results would be mediated through an ordering physician and not go directly to patients, it is peculiar that it did not place the fiduciary obligations there with the physician.51

In March of 2014 - motivated by strong condemnations that patients should be able to opt out of the analysis of SFs - the ACMG updated its recommendations to respect individuals' "right not to know" their genotype.52 The new recommendations allow patients to indicate that they would not like to receive SFs, through the advanced informed consent process.53 In the future, it is possible that informed consent procedures will take care of much of the issues presented in this article, as patients can let their physician and laboratory know what types of SFs they would like to have disclosed.54 But as most informed consent documents struggle to anticipate every contingency, adequately define terms, respond to evolving clinical information, and present information in a way that is easily understood by patients, this dilemma over the return of SFs will not be solved by informed consent procedures. This also assumes that the institution requires some form of express consent before submitting tissue for genetic analysis, which not all clinics do.55 Further, the duty to warn is not coterminous with what a patient has expressly agreed to be told in

46 SF Lucy-Enid Ding, Leslie Burnett \& Douglas Chesher, The Impact of Reporting Incidental Findings from Exome and Whole-Genome Sequencing: Predicted Frequencies Based on Modeling, 17 GENETICS IN MED. 197, 204 (2014)(finding that the riskier the intervention given the benefits, the less likely the SF mutation should be reported by the lab). Kalia, supra note 39, at 250 (studying the likelihood of SFs based on the ACMG criteria calculated that $2.7 \%$ (range: $1.5-6.5 \%$ ) of screened individuals would have a reportable).

47 Green, supra note 32 , at 569 .

$48 \mathrm{Id}$. at 568.

49 RESTATEMENT (THIRD) OF AGENCY $\$ 8.01$ (AM. LAW. INST. 2017).

50 See Gabriel Lázaro-Muñoz, The Fiduciary Relationship Model for Managing Clinical Genomic

"Incidental" Findings, 42 J. LAW MED. ETHICs 576, 3 (2014).

51 Green, supra note 32, at 568-70.

52 Anastasia Richardson, Incidental Findings and Future Testing Methodologies: Potential Application of the ACMG 2013 Recommendations, 1 J. OF L. AND THE BIOSCIENCES 378, 381 (2014).

53 ACMG Board of Directors, ACMG Policy Statement: Updated Recommendations Regarding Analysis and Reporting of Secondary Findings in Clinical Genome-Scale Sequencing, 17 GENETICS IN MED. 68, 68 (2014).)

54 Id.

55 See A Helpful Introduction to Torts, LAWS.COM, https://tort.laws.com/torts (last visited March 13, 2018). 
advance. The very idea that courts can impose duties through tort law suggests that these legal obligations override what parties agree to in advance through negotiation or contract. Tort duties exist in addition to, or instead of, contractual obligations.

In the future, interoperable medical records might help avoid this dilemma because the lab could return the SFs to the physician and import the data into a searchable electronic medical record. Then at a later encounter when the physician meets with the patient, the physician could ask the patient whether she would like to know about this particular SF. If warranted, the physician could also request a consult with a genetics counselor to help the patient understand the SF and put it in context. This technological tool would greatly assist the transmission of SFs to patients in a responsible way. But it too falls short of solving the present problem of whether labs might have some affirmative duty to reach out to a non-consenting patient and offer information regarding SFs before it becomes clinically relevant.

While the ACMG report provides some professional guidance to clinical laboratories, it does not answer the question of whether they might face tort liability for failing to return SFs. Ethical obligations do not automatically create legal obligations. Applying common law principles from negligence and the duty to warn, this article concludes that while there might be ethical obligations to return particular SFs to patients, there should not presently be any legal obligation to do so.

\section{Applying The Inelegant But Flexible LaW OF Negligence}

Torts like negligence provide a flexible means compensating injured parties. But the system offers an inefficient means to ensure patient safety and autonomy. By the time a plaintiff files suit, the injury occurred and the plaintiff has already suffered injury. There are also major disincentives to filing a lawsuit, such as lost time and the emotional distress from litigation.56 Even in the unusual case where a plaintiff is paid a settlement or receives damages, a third of anything a plaintiff receives typically goes to the attorneys. Without political will and targeted regulation, tort law can provide some compensation and possible deterrence for careless actions.57 In Williams v. Quest Diagnostics case, a mother sued the lab after it conducted her son's genetic testing for Dravet's disease under the theory that its failure to label her son's SCN1A mutation as

disease-causing led to his death. ${ }^{58}$ In such a case, tort law provides the only means of

56 See, e.g., Michael C. Dorf, How Should Courts Handle Frequent Fliers? A Trampling Incident at a Florida Wal-Mart Highlights a Dilemma, FINDLAW (Dec. 10, 2003), http://supreme.findlaw.com/legalcommentary/how-should-courts-handle-frequent-filers.html.

57 See generally A Helpful Introduction to Torts, LAWS.COM, https://tort.laws.com/torts (last visited Feb. 25, 2018).

${ }^{58}$ Jennifer Wagner, Litigating the Accountability of Clinical Genomics Laboratories, Genomics Law Report, GENOMICS L. REP., https://www.genomicslawreport.com/index.php/2016/05/31/litigating-the-accountability-ofgenomics-laboratories/ (last visited Feb. 26, 2018)(“More than 1250 epilepsy-causing mutations have been reported in this gene, and about $95 \%$ of patients with Dravet syndrome have de novo heterozygous mutations (meaning the parents do not carry the mutations").). 
compensation.59 There is no other criminal, statutory, contract or regulatory remedy.60 It's a tort law remedy or nothing.

In any negligence action, the plaintiff must prove that the defendant breached a duty it owed to plaintiff, causing an injury the law finds worthy of compensation. Essentially, a plaintiff must prove four elements : (1) duty; (2) breach, ; (3) causation; and (4) injury.61 If the plaintiff cannot prove these by the preponderance of the evidence, she loses. And this is before a defendant raises any affirmative defenses. 62

In the U.S., the common law of tort has traditionally emphasized whether the defendant's action - rather than his inaction-injured the plaintiff.63 The law expects people to conduct themselves in reasonable and careful ways, but the law will not hold defendants liable for negligence due to inaction unless their previous action caused the risk of harm. 64 Generally, a defendant has no "duty to rescue." 65 Even where the defendant "realizes or should realize that action on his part is necessary for another's aid or protection," the Second Restatement of Torts recognizes that this "does not of itself impose upon him a duty to take such action."66 Thus, a lab's belief that disclosure could prevent harm to a patient does not create a tort duty to disclose. The U.S.is unusual in this regard, most European countries impose some duty to rescue by statute. Only three states in the U.S. have imposed, by statute, an affirmative duty for private citizens to rescue strangers. 67

59 Jennifer Wagner, Litigating the Accountability of Clinical Genomics Laboratories, Genomics Law Report, GENOMICS L. REP., https://www.genomicslawreport.com/index.php/2016/05/31/litigating-theaccountability-of-genomics-laboratories/ (last visited Feb. 26, 2018)(“More than 1250 epilepsy-causing mutations have been reported in this gene, and about $95 \%$ of patients with Dravet syndrome have de novo heterozygous mutations (meaning the parents do not carry the mutations").

60 See Tort, LEGAL INFORMATION INSTITUTE, https://www.law.cornell.edu/wex/tort (last visited Feb. 25, 2018).

61 See David G. Owen, The Five Elements of Negligence, 35 HofSTRA L. REv. 1671, 1672 (2007).

62 See Carl Barbier and Donna Phillips Currault, Fundamentals of Rule 12, FBA NO CHAPTER (Mar. 26, 2015), http://nofba.org/wp-content/uploads/Fundamentals-of-Rule-12.pdf.

63 See Jennifer L. Groninger, No Duty to Rescue: Can Americans Really Leave a Victim Lying in the Street? What is Left of the American Rule, and Will it Survive Unabated?, 26 PEPPERDINE L. REV. 353, 376 (1999).

64 Steven R. Smith \& Robert G. Meyer, Law, Behavior, and Mental Health: Policy and PRACTICE 41 (1987).

65 Marin Roger Scordato, Understanding the Absence of A Duty to Reasonably Rescue in American Tort Law, 82 TUL. L. REV. 1447, 1459 (2008) ("In the midst of this more or less pervasive obligation of reasonable precaution and care generated by the operation of negligence law, there exists a black hole, a small void in which the duty of reasonable care does not apply.").

66 RESTATEMENT (SECOND) OF TORTS $\$ 314$ (Am. L. Inst.1965).

67 Vermont, Rhode Island, and Minnesota have enacted statutory duties to rescue. According to David Hyman, "Vermont and Rhode Island require individuals to perform non-risky rescues; Minnesota requires individuals to either perform the non-risky rescue or provide notice of the problem to police or rescue personnel. One other state, Wisconsin, has a statute that requires persons present at the scene of a crime to either report the incident to the police or to assist the crime victim. Several other states have imposed limited duties to report crimes, and every state imposes a duty to remain at the scene of a car accident at least long enough to render aid and exchange information, when it is safe to do so." David A. Hyman, 
Over the course of the last forty years, this distinction between action and inaction-also known as misfeasance and nonfeasance in torts parlance - has eroded. Where certain policy factors are present, and the plaintiff stands in some "special relationship" with the defendant, most state courts recognize that a defendant may be considered negligent for failing to act.68 Despite the general expansion of the notion of duty in recent years, this expansion is not without limits. The typical cases where courts impose an affirmative duty to warn can be easily distinguished from the return of SFs in asymptomatic individuals. The remainder of this article will address the contexts in which courts have been willing to impose an affirmative duty to warn.

\section{The History and Expansion OF A Duty To Warn in Negligence}

The threshold legal question in a negligence action is whether the defendant owed a duty of care to the plaintiff. ${ }^{69}$ And duties are about relationships. It is typically not enough for the plaintiff to show that the defendant owed a duty "to the world at large or to some other person, but instead plaintiff must show that he was within a class of persons to whom the defendant owed a duty to refrain from the allegedly negligent or wrongful conduct."70 As torts scholar Dean Prosser put it, "duty... is a question of whether the defendant is under any obligation for the benefit of the particular plaintiff."71 In most cases, it is obvious that the defendant owed the plaintiff a duty to take care not to cause the type of injury that she suffered. We all owe a duty to drive our cars carefully so as not to injure others on the road. Contractors owe a duty to build safe houses for anyone who might use the house. Pharmacists have a duty to the patients whose medicines they dispense owe .72 It is often assumed that the defendant owes the plaintiff a duty, so the parties do not litigate this element.73 But in cases based on novel relationships, the question of whether the defendant owed the particular plaintiff a duty is complex. Nowhere is this trickier than when the law expects the defendant not to be careful when acting, but to be careful by acting. Courts are reluctant to impose an affirmative duty to act if the default or baseline is no action.

Whether to impose a duty is "an expression of the sum total of those considerations of policy which lead the law to say that the particular plaintiff is entitled to protection' against the defendant's conduct."74 Unlike the other fact-dependent elements of the negligence cause of action - determinable by juries - judges determine whether the defendant owed a duty of care to the plaintiff. 75 This is because the imposition of a duty involves questions of public policy. As judges are better positioned to evaluate the social costs and benefits of imposing a duty, this

Rescue Without Law: An Empirical Perspective on the Duty to Rescue, 84 TEX. L. REV. 653, 683-84 (2006).

68 RESTATEMENT (SECOND) OF TORTS § 314A (Am. L. Inst.1965). )

${ }^{69}$ D.E. Buckner, Comment Note- Foreseeability as an Element of Negligence and Proximate Cause, 100 A.L.R.2d 942, §2[a] (1965).

$70 \mathrm{Id}$.

$71 \mathrm{Id}$.

72 John Goldberg, Anthony Sebok, and Benjamin Zipursky, TORT LAW: RESPONSIBILITIES AND REDRESS $52\left(4^{\text {th }}\right.$ ed 2106).

$73 \mathrm{Id}$. at 51 .

74 Beauchene v. Synanon Foundation 88 Cal. App. 3d 342,348 (quoting William L. Prosser, ToRTs 325-

26 (4th ed. 1971)); Dugard v. United States, 835 F.3d 915, 921 (9th Cir. 2016).

75 See Leon Green, The Duty Problem in Negligence Cases, 28 COLUM. L. REV. 1014, 1022 (1928).

Comment [r2]: Cite

Explain why this is obvious 
responsibility falls to them.76 Of course, this gives judges power in negligence cases. Judges can take a case away from the jury and resolve it themselves if they decide that this class of defendants owes no duty to this class of plaintiffs, even if the defendant caused the plaintiff's injury through his unreasonable behavior.77 This power might be shocking to those who are not familiar with tort law. The recent Third Restatement of Torts reflected a concern that judges may take too many cases away from juries on grounds of duty, and cautioned against this state judge behavior.78 Even so, it seems that courts still exercise this control over their dockets.

\section{Crucially, There is nO “Special Relationship” Between The LaB AND Patient}

Whether a duty exists is intimately related to the question of the content of the duty. It is possible for a person to owe no duty of care in one context, a minimal duty in another, and an expansive duty in a third context.79 Much hinges on whether a special relationship exists between the parties. before litigation. If there is no special relationship, courts are reluctant to impose broad, affirmative duties to rescue or warn.

Examples of typical "special relationships" are those of landlord/tenant, business/customer, airplane/passenger, school/student, hotel/guest or physician/patient.80 Tort law finds these relationships special because the subordinated plaintiff places his or her well-being or safety in the trust and control of the defendant.81 Because of the control that the landlord, business owner, and airline operator have over access to their apartments, businesses, and airplanes, customers cannot always receive help from others. With this control and power comes some fiduciary obligations to protect the vulnerable customer. 82 A more vulnerable and lesssophisticated plaintiff expects the more-powerful defendant to use heightened care.83 Courts routinely apply this dynamic to the physician/patient relationship. 84

76 See Lisa M. Nuttall, Tort Law - Foreseeability vs. Public Policy Considerations in Determining the Duty of Physicians to Non-Patients - Lester v. Hall, 30 N.M. L. REV. 351, 353, 359 (2000).

77 See Stephen A. Weiner, The Civil Jury Trial and the Law-Fact Distinction, 54 Cal. L. Rev. 1867, 1867 (1966).

78 See George W. Soule and Jacqueline M. Moen, Failure to Warn in Minnesota, The New Restatement on Products Liability, and The Application of the Reasonable Care Standard, 21 William Mitchell L. Rev. 389, 389, 392 (1995).

79 See Jarmie v. Troncale, 50 A.3d 802, 832-34 (Conn. 2012) citing Doe v. Yale University, 659, 748 A.2d 834, 855 (Conn. 2000) (type of duty claimed can determine whether negligence claim is cognizable); Clohessy v. Bachelor, 675 A.2d 852, 860 (Conn. 1996) ("[t]he nature of the [defendant's] duty, and the specific persons to whom it is owed, are determined by the circumstances surrounding the conduct of the individual" [internal quotation marks omitted] ).

80 See Claire Elaine Radcliffe, A Duty to Rescue: The Good, the Bad, and the Indifferent - The

Bystander's Dilemma, 13 PePPERDINE L. ReV. 387, 395-96 (1986).

81 See id. at 395.

82 See Barbara Black, Transforming Rhetoric into Reality: A Federal Remedy for Negligent Brokerage Advice, 8 TRANSACTIONS 101, 114 (2006).

83 See Radcliffe, supra note 76, at 396. FIND SOURCE

84 See Roger B. Dworkin, Getting What We Should from Doctors: Rethinking Patient Autonomy and the Doctor-Patient Relationship, 13 HEALTH MATRIX 235, 236-37 (2003). 
It is precisely because of the special relationship between physician and patient that courts have imposed expansive affirmative obligations on physicians to warn, protect, and inform patients - and even non-patients - of foreseeable risks of harm.85 But before we can explore whether to extend the "duty to warn" cases from physicians to laboratories I will flush out the extent to which the relationship between the patient and the lab is very different from the relationship between the patient and her physician. 86

The relationship between a patient and his or her clinical laboratory is more attenuated than the relationship between patient and physician. Most patients never meet laboratory technicians. Hospitals contract with different labs, such that if a patient submits two samples, they may go to a different entity, with a different person, analyzing their samples every time. 87 Typically the ordering physician mediates the patient's sole interaction with the clinical lab. Patients do not have the same intimate conversations - based on trust and expertise - that they have with their physician. Patients do not expect loyalty from their lab and there is certainly a much less developed a canon of laboratory ethics governing the communications between lab and patient. 88 The physician-patient relationship might be fetishized because many of us no longer have intimate relationships with our primary-care doctors, let alone with specialists. But the tradition of trust, physical custody, communicative intimacy, ethics, and the unequal power dynamic generates the kind of "special relationship" courts recognize between physicians and patients. 89 These elements are not present between a patient and the clinical laboratory. Patients do not refer to their lab technician in the way that they refer to their doctor.

Some may argue that a special relationship exists between the patient and laboratory because the patient puts her tissue or blood sample into the laboratory's control and custody. But the law does not demand physical control or for a special relationship to attach. And where it is present, it is typically the custody of the whole person that creates the kind of special relationship that imposes a heightened tort duty.90 The bases for these protective obligations arises out of concerns for personal safety.91 An individual's safety is not threatened by submitting a tissue sample to a clinical laboratory.

85 See Safer v. Pack, 291 N.J. Super. 619 (1996), Gill v. Hartford Accident \& Indem. Co., 337 So.2d 420 (Fla. Dist. Ct. App. 1976); Cheeks v. Dorsey, 846 So.2d 1169, 1173 (Fla. Dist. Ct. App. 2003); Emerich v. Phila. Ctr. for Human Dev., Inc., 720 A.2d 1032, 1037-1038 (Pa. 1998).

86 An important question for deeper analysis elsewhere is whether a physician who is also a researcher can disavow the strong patient/physician relationship when he is wearing his researcher hat. The fiduciary obligation does not disappear when the physician is conducting research. The physician does not stop being the patient's physician, even if the nature of the relationship is very different, and the researcher is no longer prioritizing the patient's individual treatment. Even so, from the perspective of the patient's expectations and trust, it is likely the "special relationship" continues to exist and can support broad, affirmative duties to warn patient/subjects. See Donna T. Chen, et al., Clinical Research and the Physician-Patient Relationship, 138138 ANNALS OF INTERNAL MED. 669, 669 (2003).

$87 \mathrm{Jim}$ Gozvoda and Jeff Raasch, Hospitals Putting Their Labs in One Place, Hospitals \& HeAlth

NETwORKS, (Aug. 11, 2007), https://www.hhnmag.com/articles/8517-core-hospital-labs

88 See, How It Works, LABCORP, https://www.labcorp.com/help/using-labcorp (last visited Nov. 9, 2017).

89 Andrea Schwab, The Physician-Patient Relationship, 108 TEX. MED. Ass'N. 48, 48 (2012).

90 See id.

91 Restatement (THIRD) OF TORTS: Phys. \& EMOT. HARM § 40 (AM. LAW InST. 2012). 
Courts have gone to great lengths to preserve the sanctity and clarity of physician-patient communication. For instance, courts have refrained from imposing duties on pharmacists, ultrasonographers, and other clinical technicians out of concern that imposing a duty on these individuals might conflict with the physician-patient relationship or confuse the message delivered to the patient. 92 Courts have been reluctant to require pharmacists to identify contraindications of drugs that the physician specifically ordered, because the physician knows the patient's history better and is thought to be in as good of a position as the pharmacist to identify which drugs are best for their patients.93 While pharmacists have greater interactions with patients than labs do, courts still prefer the physician to serve as the primary clinical liaison. Funneling reporting responsibilities through the physician ensures that the patient does not receive conflicting communication, but it places a great deal of responsibility on general practitioners. Some of this might come from the "learned intermediary" doctrine in products liability.94 Under this doctrine, the manufacturer of a drug or device need not directly warn a patient, so long as it warned the "learned intermediary," a prescribing physician.95 The physician has a duty to warn the patient and the manufacturer is not liable even where the physician does not actually pass along the warning.96

While a laboratory may have better information as to which mutations are actionable, highly penetrant, or lead to severe loss of function, it must share this information with the physician, who can translate it and place it into context for the patient. 97 Pilot data suggest that patients can take SFs in stride and that patient and primary-care physician can digest such implications without unnecessarily using health care resources or becoming distressed.98 Even if

92 See Lauren Fleischer, From Pill-Counting to Patient Care: Pharmacists' Standard of Care in Negligence Law, 68 FordHAM L. REV. 165, at 168 (1999).

93 Pharmacists' Duty to Warn, NAT'L ASs'N OF CHAIN DRUg STORES,

https://www.nacds.org/pdfs/membership/duty_to_warn.pdf (last visited Dec. 22, 2017); JA Ansari, Drug Interaction and Pharmacist, 2 J. OF YOUNG PHARMACISTS 326, 329 (2010).

94 See, Fleischer, supra note 87, at 168 n. 21-22 (citing Reyes v. Wyeth Laboratories, 498 F.2d 1264, 1276 (5th Cir. 1976); Presto v. Sandoz Pharms. Co., 487 S.E.2d 70, 73 (Ga. Ct. App. 1997); Kirk v. Michael Reese Hosp. \& Med. Ctr., 513 N.E.2d. 387, 395 (Ill. 1987)).

95 See, Diane Schmauder Kane, Construction and Application of Learned-Intermediary Doctrine, 57 A.L.R.5TH 1 (1998) ("Under the circumstances presented in the cases described below, the courts concluded that a learned intermediary's negligence in prescribing, administering, or treating an injured patient was a primary, superseding cause of the patient's injuries, thereby severing the causal connection between the manufacturer's alleged inadequate warnings and the patient's ultimate injury.").

96 Carol Rooney, The Learned Intermediary Doctrine: An Update, 30 TRIAL ADVOC. Q., 6 (2010) ("The learned intermediary doctrine allows the manufacturers of prescription drugs or medical devices to defend against a claim of failure to warn brought by an injured patient by showing that they provided adequate warnings to the prescribing physician.”).

97 See 42 C.F.R. §493.1291(1) (2017), and Keyan Salari, The Dawning Era of Personalized Medicine Exposes a Gap in Medical Education, 6 PLOS 1,2 (2009).

98 Vassy, supra note 13, at 160 . However, this study was based upon a convenience sample of 9 physicians from one network in the highly-academic Boston environs. So even though the data are interesting, their reassuring findings might not extrapolate to the general primary care population, where physicians may not have the resources or knowledge to help patients interpret the data. But we do learn 
physicians need to consult genetics counselors, physicians are still better positioned to communicate nuance to the patients. Imposing this obligation on laboratories could interfere with clinical decision-making.

Because no "special relationship" exists between a clinical laboratory and a patient, the courts cannot rely on default common-law principles to impose affirmative obligation upon laboratories to warn patients of the risks of SFs. A more nuanced analysis that considers larger policy considerations. is necessary. This article will address those policy considerations, as they are enshrined in the case law.

\section{THE DEVELOPMENT OF THE ROWLAND FACtORS}

In the late 1960s, beginning in California, state judges began expanding the scope of liability by imposing new affirmative duties. Rowland $v$. Christian began this shift.99 In Rowland, the plaintiff, while visiting his friend, severed tendons in his hand while using her broken bathroom faucet. $100 \mathrm{He}$ sued his friend under a common-law negligence theory-probably because she had renter's insurance and would not be paying the damages herself - arguing that she knew about the broken faucet and therefore had a duty to warn him about it.101 Before Rowland, owners of land did not owe a duty to warn social guests of such risks, but they did have a duty to warn people invited to their homes for business purposes.102 Reflecting the egalitarian principles of the era, the court emphasized that "a man's life or limb does not become less worthy of protection by the law" because he was a social guest and not a business invitee. 103

Rowland revolutionized the duty analysis. In recognizing a new duty to warn social guests of concealed risks in their homes, Rowland established the general principle "that a person is liable for injuries caused by his failure to exercise reasonable care in the circumstances," 104 and no exception to this rule automatically applied when the injury resulted from defendant's inaction.105 Rowland could carry forward with his negligence claim. The fact that Christian had failed to actrather than acted carelessly - was no longer dispositive. Of course, the plaintiff still must prove that the defendant's behavior fell below an acceptable standard of care, causing the plaintiff's injury.106 But the case could go to trial for a jury to decide these issues.

The case opened the duty to warn to a more flexible analysis and blurred the sharp distinction between action and inaction. Judges became empowered to impose affirmative duties to warn in a broad swathe of cases. Indeed, Rowland provided the framework and justification for Tarasoff, where California imposed on psychotherapists a duty to warn identifiable non-patients

from this study that the disclosure can be a fruitful one, and does not always require the interpretation of a genetics counselor.

99 See Robert S. Driscoll, The Law of Premises Liability in America: Its Past, Present, and Some

Considerations For Its Future, 82 NOTRE DAME L. REV. 881, 881 (2006).

100 Rowland v. Christian, 443 P.2d 561, 562 (Cal. 1968)(later codified at CA Civ Code $\S 847$ (2016)).

$101 \mathrm{Id}$.

$102 \mathrm{Id}$. at 556.

$103 \mathrm{Id}$. at 568.

104 Id. at 564.

$105 \mathrm{Id}$.

$106 \mathrm{Id}$. at 568. 
of serious risk of harm.107 While Tarasoff did not require an imminent threat-indeed the defendant did not murder Tarasoff until ten weeks after discussing his threats with his psychotherapist - eighteen states and the District of Columbia require that to establish a duty to protect third-parties a threat must be either "imminent" or "immediate."108

What began with understated language from Rowland blossomed into an entirely new paradigm, where the law may impose liability for failing to act on many classes of tortfeasors. The default rule in California and now elsewhere is that the defendant owes all reasonably foreseeable plaintiffs a duty of reasonable care.109 The Rowland court provided "a number of considerations" that courts should weigh when deciding whether to depart from the general presumption of a duty.110 These factors have been cited by several hundreds of courts in many states.111 The considerations were:

(1) the foreseeability of harm to the plaintiff, (2) the degree of certainty that the plaintiff suffered injury, (3) the closeness of the connection between the defendant's conduct and the injury suffered, the (4) moral blame attached to the defendant's conduct, the (5) policy of preventing future harm, the (6) extent of the burden to the defendant and consequences to the community of imposing a duty to exercise care with resulting liability for breach, and (7) the availability, cost, and prevalence of insurance for the risk involved.112

\section{Applying the Rowland Factors to the Problem at Hand}

While the Rowland court did not tell future judges how to weigh these various factors, it has become clear that - as with traditional duty analysis - foreseeability and the magnitude of the harm receive the most weight. But the actual weight accorded to each factor depends on the case's circumstances. 113 Because of their instrumental role in developing the duty to warn, including in the context of duties owed to third parties, this article applies the Rowland factors to the potential for the laboratory's liability for failure to warn of SFs.

a. THE First FACTOR: THE ForESEEABILITY OF HARM

107 Tarasoff v. Regents of Univ. of California, 551 P.2d 334, 340-343 (Cal. 1976) ("We shall explain that defendant therapists cannot escape liability merely because Tatiana herself was not their patient. When a therapist determines, or pursuant to the standards of his profession should determine, that his patient presents a serious danger of violence to another, he incurs an obligation to use reasonable care to protect the intended victim against such danger. The discharge of this duty may require the therapist to take one or more of various steps, depending upon the nature of the case.").

108 Mark A. Rothstein, Tarasoff Duties After Newtown, 42 J.L. MED. \& ETHICS 104, 107 (2014).

109 See Calvillo-Silva v. Home Grocery, 968 P.2d 65, 71 (Cal. 1998).

110 Rowland, 433 P.2d at 564.

111 The current citation references in Westlaw lists the relevant headnote keycite being cited a whopping 616 times by other courts. Rowland v. Christian, Cases, WESTLAW, http://westlaw.com (last visited Feb. 26, 2018).

112 Rowland, 443 P.2d at 564.

113 O’Hara v. Holy Cross Hosp., 561 N.E.2d 18, 21 (Ill. 1990). 
In the positive law of all but three states, the primary touchstone of any duty analysis is whether the harm to the plaintiff is foreseeable.114 When a judge asks whether the harm is foreseeable, she does not ask whether in fact this defendant predicted the likely occurrence of an event. Rather, she asks whether the defendant should have realized that her conduct put someone else at likely risk of harm.115 In most cases this means that the harm must be likely, but not necessarily certain or even "more likely than not."116 Thus, defendants must foresee only reasonably likely harms, rather than every possibility of harm.117 In the context of a laboratory's affirmative duty to warn, a judge would need to find that the defendant should reasonably have recognized that her failure to disclose SFs would likely cause someone harm.118

The most obvious harm would be that the patient's delayed diagnosis caused her to incur greater medical expenses or receive a worse prognosis. This could arise from a physician's failing to treat something that could have been treated or prescribing the wrong medicine given the likelihood of a serious drug reaction. Of course, when it comes to causation the plaintiff must prove that the physician would have done something differently because of the SF. But this is also a component of the foreseeability analysis. Unless the performance of the duty would have prevented the injury, it makes no sense to impose it.

The laboratory must have actual or constructive knowledge that there is a reasonably possible causal link between the genotype and developing a disease for which there exists some treatment. It is this probable link that makes the risk of harm foreseeable. Without knowledge that the genetic mutation is likely pathogenic, there is nothing clinically actionable. Thus, no potential harm flows from a failure to disclose it. One version of harm contemplates not that the patient would be put on notice to pursue contemporaneous treatments, but that she might need to be extra

114 See Formet v. Lloyd Termite Control Co., 110 Cal. Rptr. 3d 551, 557 (Cal. Ct. App. 2010) ("The foreseeability of the harm, though not determinative, has become the chief factor in duty analysis."): see also Benjamin C. Zipursky, Foreseeability in Breach, Duty, and Proximate Cause, 44 WAKE FOREST L. REV. 1247, 1257-1258 (2009)(The Reporters of the recent Restatement of Torts reject the reliance on foreseeability in the analysis of duty, but in so doing, they "risk damaging the credibility of the Restatement (Third) as a 'restatement' by declining to put foreseeability in the black letter"... as "foreseeability is overwhelmingly embraced by American courts as a vitally important part of duty analysis." To varying degrees, Washington, New York, and Arizona courts have expressed some disfavor with relying too much on foreseeability in analysis of duty.).

115 Robert H. Dierker and Richard J. Mehan, 34 Mo. Prac., Personal InJuRY and Torts HANDBOOK, §2:6 (2016 ed.) ("Foreseeability is established when "the evidence indicates that the defendant had actual or constructive knowledge that there was some probability of a sufficiently serious injury that an ordinary person would take precautions to avoid it.").

116 See Chapman v. Mayfield, 361 P.3d 566, 572 (Or. 2015)(“It is not necessary that the risk of harm be more probable than not; rather, the question is whether a reasonable person considering the potential harms that might result from his or her conduct would "have reasonably expected the injury to occur."). 117 BARRY A. LINDAHI, Existence of duty in MODERN TORT LAW: LIABILITY AND LITIGATION $\S 3: 17$ (2d ed. 2017).

118 Restatement (Third) of Torts: Liability \& Physical Harm § $41 \mathrm{cmt}$. c (Am. Law. Inst. 2010) ("When no reasonable jury could find that there was a foreseeable risk of harm or a failure to exercise reasonable care, courts find no liability as a matter of law."). No one is expected to "warn" people of things that pose no risk; indeed, this is the very nature of a warning in that it communicates some impending danger or threat. 
vigilant for warning signs that she was developing the disease, so that she could catch it and treat it early. But even in the "need for medical monitoring" case, the harm is a missed opportunity for a potentially successful clinical intervention. If a physician cannot do anything to mitigate the genetic risk, there is no duty for the physician to "warn" of the latent genetic risk.

We cannot say, in the abstract, whether the risk of harm from non-disclosure of SFs is foreseeable.119 Foreseeability, therefore, hinges on such things as the type of information the laboratory conveyed, to whom it conveyed the information, and the seriousness and specificity of the warning. Specifically, the notion of genetic penetrance plays a huge role in these types of cases because it makes the foreseeability analysis more complex and less clear-cut than it is in other duty to warn cases.

\section{i. What is Penetrance And How Does it ImPaCt THE Foreseeability ANALysis?}

Penetrance - an important factor in the foreseeability analysis - played a role in the ACMG report. If penetrance is low, then many people with a genetic mutation will never develop the phenotype, even if they have one of the associated markers. 120 For example, many people with mutations in the BRCA1 or BRCA2 genes - those associated with lung and ovarian cancer-will develop cancer during their lifetime, but almost as many people will not.121 Currently, geneticists cannot predict which people with these mutations will develop cancer or when the tumors will develop, though a family history certainly increases risk.122 Due to the influence of hard-tomeasure environmental factors and the low base rates of some diseases in the population, geneticists will probably never forecast, with high predictive values, who will develop many complex cancers such as breast or ovarian cancer.123

A study of symptomatic individuals, found the following mean cumulative cancer risks for mutation carriers at age 70 years: "a breast cancer risk of $55 \%$ for BRCA1 and $47 \%$ for BRCA2 mutation carriers; and an ovarian cancer risk of 39\% for BRCA1 and $17 \%$ for BRCA2 mutation carriers." 124 While a breast cancer risk of $57 \%$ certainly seems sufficient to constitute "foreseeable," this figure is not an accurate predictor. Because studies have not tracked many people with the genotype who do not also have the phenotype. Current estimates represent the average risk for people who already have symptoms of cancer, and usually a family history of cancer.125 For the individuals tested for some other reason-and not specifically tested for

119 PRESIDENTIAL COMM'N FOR THE STUDY OF BIOETHICAL IsSUES, FOR RESEARCHERS: INCIDENTAL AND SECONDARY FINDINGS (2016), available at:

https://bioethicsarchive.georgetown.edu/pcsbi/sites/default/files/Researcher\%20Primer\%20Incidental\%20 Findings\%2010.30.16.pdf.

120 See Robert C. Green et al., ACMG Recommendations for Reporting of Incidental Findings in Clinical Exam and Genome Sequencing, 15 GENETICS IN MED. 565, 568 (2013).

121 BRCA1 and BRCA2: Cancer Risk and Genetic Testing, NAT'L CANCER INST. (Apr. 1, 2015),

https://www.cancer.gov/about-cancer/causes-prevention/genetics/brca-fact-sheet.

122 Id.

123 C. Marzuillo, et al., Predictive Genetic Testing for Complex Diseases: A Public Health Perspective,

107 Q. J. MED. 93 , 94 (2014).

124 Sining Chen \& Giovanni Parmigianni, Meta-Analysis of BRCA1 and BRCA2 Penetrance, 11

25 J CLIN ONCOL. 1329, 1333 (2007).

$125 \mathrm{Id}$. at 1330 . 
BRCA1 or BRCA2 - their risk of developing the disease will be lower.126 These patients are not likely to be symptomatic and probably do not have a family history of breast or ovarian cancer that served as the basis for having the genetic test.127

Further, the penetrance and risk factors for everyone are always changing, as global environmental changes such as pollution and chemical exposure can lead to "birth cohort effects", where older women - a group of people born before 1940 - have lower penetrance risk than younger women born after 1940, or in a later "birth cohort".128 The birth-cohort effect demonstrates that for some diseases, penetrance risks change at the population level, which probably relates to increased or decreased environmental risks, although these changes are undetectable for generations.129 As penetrance decreases, judges should not impose a duty to disclose the risk of developing disease.

Similar to disease-prediction, the penetrance and expression of pharmacogenomics can be complex, making the foreseeability of harm to any individual difficult to assess.130 Pharmacogenomics studies how genetic mutations can predict drug metabolism and adverse drug reactions.131 While genetic factors contribute to adverse drug reactions, the extent of the genetic contribution varies depending on the person and the disease process.132 This makes it "difficult to estimate in quantitative terms the contribution of genetic factors relative to other non-genetic factors in predisposing to specific [adverse drug reactions]." 133 While it is becoming easier to predict adverse drug reactions caused by a small number of genetic mutations, predicting complex traits, involving multiple mutations with small effects, is "almost impossible in the foreseeable future."134 Only if the penetrance and expression will lead to significant harm should the lab have

126 See BRCA1 and BRCA2: Cancer Risk and Genetic Testing, NAT'L CANCER INST. https://www.cancer.gov/about-cancer/causes-prevention/genetics/brca-fact-sheet (last updated Jan. 30, 2018).

127 D Gareth Evans, et al., Long-term prospective clinical follow-up after BRCA1/2 presymptomatic testing: BRCA2 risks higher than in adjusted retrospective studies 51 J. MED. GENETICS 573, 573 (2014) ("“Breast cancer risks in large familial breast cancer kindreds with BRCA1/BRCA2 mutations are substantially higher than risks derived from population-based [asymptomatic or presymptomatic] studies.").

128 Mary Claire King, et al, Breast and Ovarian Cancer Risks Due to Inherited Mutations in BRCA1 and $B R C A 2,302$ SCIENCE 643, Figure 1 (2003) ("Age by age, breast cancer risks for mutation carriers born after 1940 were significantly higher than risks for mutation carriers in the same families born before 1940.”).

129 Mary Claire King, et al, Breast and Ovarian Cancer Risks Due to Inherited Mutations in BRCA1 and BRCA2, 302 SCIENCE 643, Figure 1 (2003) (“Age by age, breast cancer risks for mutation carriers born after 1940 were significantly higher than risks for mutation carriers in the same families born before 1940.").

130 Alfirevic, supra note 5, at 100 ("However, it has been estimated that approximately 20-30\% of ADRs could be prevented by pharmacogenetic testing.").

131 Urs A. Meyer, Pharmacogenetics and Adverse Drug Reactions, 356 LANCET 1667, 1667 (2000). 132 Id.

133 Alfirevic, supra note 5, at 100. Ana Alfirevic and Munir Pirmohamed, Genomics of Adverse Drug Reactions, 38 Trends in Pharmacological Sciences 100 (2017)

134 Ge Zhang and Daniel Nebert, Personalized medicine: Genetic risk prediction of drug response, 175

PHARMACOLOGY AND THERAPEUTICS 75 (2017) [hereinafter Zhang]. 
any duty to warn the patient, through her provider, of this SF.135 But if the likelihood of ever needing a particular drug is incredibly low, there may be no duty to warn.

Let us consider a particular example to assess the foreseeability of harm. justified imposing upon a laboratory the duty to warn The best example of this is the use of Human leukocyte antigen (HLA-B) testing to prevent abacavir hypersensitivity, a severe adverse reaction to an HIV drug, which can cause death.136 The utility of HLA-B testing has been demonstrated in controlled trials and its predictive value and cost-effectiveness has been assessed in different ethnic groups and healthcare settings.137 And yet, it might still not overcome the hurdles of foreseeability and imminence because, it is quite unlikely that an individual would develop HIV and require abacavir.138 In this type of scenario, it is more appropriate to put this duty-to-warn on the infectious-disease doctor who prescribed abacavir. Presumably, the doctor is better positioned to know the adverse-drug reactions for the drugs they routinely prescribe. The doctor should test all patients the HLA-B marker before administering abacavir.139 As the list of SFs continues to grow, patients cannot be expected to retain this information for future, potential, clinical use. 140

As with other genetic SFs, there will be many false positives due to the rarity of these adverse-drug events and incomplete penetrance and environmental risk factors. 141 But the risk of false positives for adverse drug reactions is less catastrophic than with disease-causing SFs. because the issue is not about a patient receiving stressful news that she might develop cancer or Alzheimer's disease. Instead, the issue is about warning her that should she ever need a particular drug, if there is an available and reasonable substitute, she should take it instead. This presents a very different cost-benefit analysis and makes it less likely someone would choose not to receive a warning.

\section{ii. What IS EXPRESSION AND HOW DOES IT IMPACT THE FORESEEABILITY ANALYSIS?}

Another important factor in the foreseeability analysis is variable expressivity, which captures the idea that a disorder's severity can change from one person to the next, even though they possess the same disease-causing genetic mutation.142 For example, some people with Marfan's disease are taller than average with long fingers, while others may also experience life-

135 Id.

136 Alfirevic, supra note 5, at 102 .

137 Id.

138 HIV in the United States: At A Glance, CDC,

https://www.cdc.gov/hiv/statistics/overview/ataglance.html (last updated Nov. 29, 2017).

139 LAURA DEAN, Abacavir Therapy and HLA-B*57:01 Genotype, in MEDICAL GENETICS SUMMARIES 7 (2015).

140 The increasing use of electronic, interoperable medical records provides an exciting technological fix to this problem, where SFs can be stored in a medical record and physicians can be notified of them when and if the SF becomes clinically relevant. See Nicole Weiskopf \& Chunhua Weng, Methods and Dimensions of Electronic Health Record Data Quality Assessment: Enabling Reuse for Clinical Research, 20 JAMA 144, 144.

141 Zhang 2017, supra note 132.

142 David N. Cooper et al., Where Genotype is Not Predictive of Phenotype: Towards an Understanding of the Molecular Basis of Reduced Penetrance in Human Inherited Disease, 132 AM. J. HUM. GENETICS 1077, 1078 (2013).
Comment [s4]: This information should be moved to page 18 where you introduce this topic.

Comment [MOU5R4]: That makes sense to me. Maybe just refer back to this part then, infra. 
threatening heart and circulatory symptoms.143 Variable expressivity affects the analysis of duty because a disease that presents in varying intensity (could be negligible, could be debilitating) reduces the certainty of significant harm. This, in turn, makes the average risk less foreseeable and reduces the pressure to impose a duty to warn. The genetics of many disorders are complex and there is still quite a bit unknown about whether a mutation will lead to severe disease.144 Environmental factors can increase or decrease penetrance and expression, as can the presence of other genetic mutations that amplify or soften the effect of a deleterious mutation.145 Defendants generally do not have duties to warn of minimal or trivial risks.146 If judges take seriously the complexity of genetic causes of disease, judges should be reluctant to extend a duty for labs to warn of SFs with the potential for minimal and benign expression.

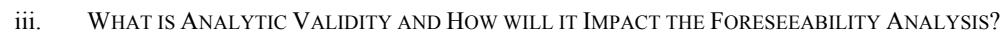

In addition to expecting false positives due to incomplete penetrance, there will also be many false negatives, particularly when the laboratory analyzes the sample using WES. Researchers have warned that clinical-exome sequencing to interpret and report particular genes "requires recognition of the substantial possibility of inadequate depth and breadth of sequencing coverage at clinically relevant locations," which will contribute to false-negatives. 147 This is a problem because the ACMG report recommended that every clinical-exome test report on 59 genes, even though the analytical validity of exome sequencing for these mutations may be of insufficient quality.148 Poor quality occurs because the test would not validate the exome screen for locating SF mutations. This means that the developers of the exome sequencing screens recognize that there is a lot of noise and clutter in the haystack that is searched.149 Significant things can be missed and insignificant things can be found. In order to confirm to confirm or diagnose the presence of a mutation, one would not use exome sequencing to do it.150 After an initial positive finding on exome sequencing, the physician would follow up with a targeted test that is validated at finding a particular needle in the vast haystack.151 There are a few technical reasons why the exome sequencing is not good at diagnostics. First, the exome sequencing does not cover everything. Estimates of the coding sequence not covered by exome sequencing range

$143 I d$. at 1077.

144 Id. at 1079. See also What Do We Mean by 'Duty to Warn?', Am. PsyChiATRIC Ass'N (Jan. 16,

2018), https://www.psychiatry.org/news-room/apa-blogs/apa-blog/2018/01/what-do-we-mean-by-duty-towarn [hereinafter Duty to Warn].

$145 \mathrm{Id}$. at 1079

146 What Do We Mean by 'Duty to Warn', AM. PSYCHIATRIC Ass'N (Jan. 16, 2018),

https://www.psychiatry.org/news-room/apa-blogs/apa-blog/2018/01/what-do-we-mean-by-duty-to-warn [hereinafter Am. Psychiatric Ass'n].

147 Jason Park, et al., Clinical Exome Performance for Reporting Secondary Genetic Findings, 61

CLINICAL CHEMISTRY 213, 220 (2015).

148 Id. at 213.

149 Clinical Whole Exome Sequencing Informed Consent, N.Y. Genome Ctr., http://www.nygenome.org/wp-content/uploads/2016/05/NYGC-Clinical-Whole-Exome-

Sequencing.pdf (last updated Jan. 27, 2106).

150 Whole Exome Sequencing, Baylor Miraca, 5, https://www.bcm.edu/research/medical-geneticslabs/?pmid=22653 (last visited Apr. 4, 2018).

$151 \mathrm{Id}$. at 2. 
from 1.4 to $39.1 \% .152$ Coverage will vary based on the quality parameters of the test and its minimum depth coverage, the source of the DNA, whether blood or saliva, the density of GC nucleotides, how the sequence is chemically enriched before being analyzed, and the method of sequencing. 153 The in terms of assessing the results of whole-exome sequencing is extremely important.

The ACMG working group anticipated the need for validation when it acknowledged that Sanger sequencing or other approaches would need to "fill in" the slower and more thorough tests, if the gene were being evaluated for a primary diagnosis. 154 The working group also reiterated that it did not recommend disclosing SFs where the primary genetic cause is a structural variant, repeat, or copy-number variant - because exome sequencing is not a reliable technology for measuring these - and the ACMG did not want to recommend "that laboratories utilize orthogonal techniques to search for these variants." 155 While the disclaimer is necessary, it reveals the false assurance that can stem from whole exome sequencing. Namely, a patient might incorrectly assume that negative findings means no genetic defects, when in reality they might have a series of complex mutations that ACMG just does not suggest reporting. If it becomes common clinical practice to return SFs, patients might expect that a negative means they are "free and clear" of genetic risk, when in fact that is not the case. 156

The lack of consensus on reporting false negatives, plus the variability in rates of false negatives illustrates that the foreseeability analysis is not straightforward.157 Laboratories are not casting out perfect nets, and if they catch fish, they are not real, actual fish. Some of the "fish" caught in the SF net are fake, due to cheaper, less thorough, exome sequencing. And the nets miss lots of fish, too. To run targeted, validated genetic tests for each of the fifty-nine ACMG mutations, and any additional mutations that predict serious drug reactions, would require too much financial and time resources of laboratories. The lack of robust analytical validity in the WES context substantially impairs the foreseeability of future harm factor.

\section{iv. SUMMARY OF THE FORESEEABILITY FACTOR ANALYSIS}

Unlike traditional duty-to-warn cases, the risks presented by SFs is highly-variable and depends on factors such as genetic penetrance and expression. Further, the number of false positives and false negatives likely from WGS and WES makes the risk of harm from nondisclosure even less likely. This makes it difficult to say that, in the abstract, the risk of harm for non-disclosure is foreseeable enough to impose an affirmative duty on laboratories to warn patients of SFs. But courts may not frame the analysis in this way.

Courts should analyze foreseeability in the abstract, and not as applied to a particular plaintiff. But courts can interpret this "abstract duty" a little less abstractly. For example, even in

152 Id. at 220 (Park).

$153 I d$.

154 Id.

155 Robert C. Green, et al., supra note 33, at 567.

156 Id.

157 Jason Park, et al., Clinical Exome Performance for Reporting Secondary Genetic Findings, 61.1

CLINICAL CHEMISTRY 213-220 (2015) 
the landmark case of Tarasoff, the duty was not an absolute duty to warn anyone of a patient's threats. ${ }^{158}$ It was limited factually to only warning of serious threats to identifiable people. For example, one cannot say that the risk of non-disclosure of all SFs is reasonably likely to cause harm.159 If you narrow the inquiry to SFs that are disease-causing, highly-penetrant, have low variance in expression, and high-analytic validity, then the foreseeability of harm is greater. But narrowing the question in this way is a much more fact-intensive inquiry, and therefore courts should instead focus on the breach-element of breach, rather than the negligence analysis.

But judges might, in some circumstances, find this sort of remote harm foreseeable. Judges are human and are vulnerable to subconsciously reframing arguments in favor of an award of damages where someone could have prevented a lost chance of a better outcome. It is very difficult to draw a sharp line between a preferred abstract inquiry and a fact-specific one. Even the most uncontested duty analyses involve fact-finding under the foreseeability prong of the analysis. But it is important that just because a harm is conceivable to a particular person does not mean it was foreseeable to a large group of potential plaintiffs ex ante.

Even if a judge included fact-specific inquiries - such as penetrance, expression, and analytic validity of a positive result for a genetic mutation) into her analysis of foreseeability, finding that the risk of harm was foreseeable does not end the debate. Foreseeability is the first factor, as "[m] any harms are quite literally foreseeable, yet for pragmatic reasons, no recovery is allowed...[a] ...further inquiry must be made...."160 Let us proceed with this further inquiry, and turn

b. The Second Factor: The Plaintiff Must Have Suffered A Certain, Concrete Harm

The second Rowland factor considers the degree of certainty that the plaintiff suffered harm. It imposes a check on liability for intangible - or purely emotional-harms. Courts are reluctant to impose an affirmative duty to warn where the harm is not capable of easy measurement or proof.161 Thus, the type of injury alleged matters a great deal. In traditional negligence claims, plaintiffs can allege emotional, physical, property, or purely-financial damages.But the parties rarely litigate the degree of certainty of harm in duty-to-warn cases, because the harm that materialized is obvious.162 Where a plaintiff alleges either nominal damages, speculative harm, or the threat of future harm, however, courts will declare a non-suit because the defendant had no duty to warn of these kinds of futuristic or intangible harms.163

${ }^{158}$ Tarasoff v. Regents of Univ. of California, 17 Cal. 3d 425, 431, 551 P.2d 334, 340 (1976) 159 Negligence, LEGAL INFO. INST., https://www.law.cornell.edu/wex/negligence (last visited Feb. 24, 2018) and Duty to Warn, supra note 140.

160 Munn v. Hotchkiss School, 795 F.3d 324, 331 (2d Cir. 2015).

161 Kesner v. Superior Court, 384 P.3d 283, 293 (Cal. 2016) ("The second Rowland factor, the degree of certainty that the plaintiff suffered injury, 'has been noted primarily, if not exclusively, when the only claimed injury is an intangible harm such as emotional distress.' Courts have occasionally included under this factor concerns about the existence of a remedy.").

162 Am. Psychiatric Ass'n, supra note 142; see also Emerich, 720 A.2d at 1032.

163 Describing the idea that even where the defendant owes a duty to the plaintiff, there must be a cognizable, realized injury to the plaintiff in order for recovery in tort. Increasing the risk of harm, or "inchoate" harm, is not enough. See John C.P. Goldberg \& Benjamin C. Zipursky, Unrealized Torts, 88 Va. L. Rev. 1625, 1638 (2002). 
Construction defects makes this concept clear. Courts have found that breaches which "have not ripened into property damage, or at least into involuntary out-of-pocket losses, do not comfortably fit the definition of an 'appreciable harm'-an essential element of a negligence claim."164 There is no common law negligence suit if construction defects have not yet caused a real harm.165 A plaintiff can sue once the pipe leaks turns from a potential to an actual injury. As courts have been reluctant to impose a duty in cases where the harm is purely emotional or financial-without accompanying physical injury to person or property-courts might be particularly reluctant to do so when expanding affirmative duties to warn.166

As applied to the genetic-sequencing context, plaintiffs must demonstrate some present, ripe, cognizable injury from the lab's failure to disclose an SF. If the plaintiff has died or incurred significant medical expenses and alleges the defendant's breach caused these injuries, this factor will not prevent recovery. But where the plaintiff is still alive and has alleged that she suffered "lost chance" of survival due to defendant's breach or a speculative future harm, courts are less likely to impose a duty to warn for this kind of intangible, difficult-to-quantify, harm. Typically the harms must concretely materialize.

c. The Third Factor: There Must Be A Close Connection Between Defendant's Conduct and THE INJURY SUFFERED

Causation - an element independent of negligence - also comes into play as the third Rowland factor. Under the analysis of duty, the "close connection between defendant's conduct and the injury suffered" serves to further narrow the class of obligations for which the defendant had a duty to warn. 167 In our hypothetical case, plaintiffs must prove that knowledge of SFs would have resulted in different clinical treatments, which would have prevented their legally cognizable injuries. Plaintiffs, as a class, cannot prove that disclosure of the SF would have prevented the injury, attenuated permit. A cancer-ridden patient would struggle to prove a wrongful death action because the patient would have to prove that knowledge of an SF would have prevented his or her premature death. This is because it will be hard to prove, given their cancer, that they would probably have lived if they had known about the SF. Further, not all diseases are preventable. For example if the SF indicated that the patient was at risk for a type of early-onset dementia, then the

164 Davies v. Krasna, 535 P.2d 1161, 1172 (Cal. (1975); see San Francisco Unified School Dist. v. W.R. Grace \& Co., 37 Cal.App.4th 1318, 1327-1331, [the presence of asbestos products in buildings did not, prior to the release of friable asbestos, constitute actual and appreciable harm under Davies v. Krasna]. 165 Aas v. Superior Court, 12 P.3d 1125, 1137-38 (Cal. 2000) (superceded by statute to provide a right to sue, acknowledging that the legislature needed to impose this duty as it did not exist through common law). The general premise still remains, however, that "[t]he mere breach of duty — causing only nominal damages, speculative harm or the threat of future harm not yet realized - normally does not suffice to create a cause of action.” San Francisco Unified Sch. Dist. v. W.R. Grace \& Co., 37 Cal. App. 4th 1318, 1326, 44 Cal. Rptr. 2d 305, 309 (1995). For application of the requirement of "appreciable harm" for tort recovery in different contexts, see Massachusetts Elec. Co. v. Fletcher, Tilton \& Whipple, P.C., 394 Mass. 265, 268, 475 N.E.2d 390, 391 (1985).

166John C.P. Goldberg \& Benjamin C. Zipursky, Unrealized Torts, 88 Va. L. Rev. 1625, 1659-1602 (2002).

167 Watkinson v. MortgageIT, Inc., 2010 U.S. Dist. LEXIS 53540 (S.D. Cal., June 1, 2010).
Comment [s7]: If you Shepardize this case, it has a red stop sign.

Comment [MOU8R7]: Yes, it was superceded by statute after I wrote this article (Jan of this year). But the need for legislative action to impose a duty only reinforces my point that judges would not impose a tort duty through common law - it needed to be imposed by statute. But I can find another source for this proposition, as it's not a unique holding. If you want to remove reference to the leaky pipes case and just use the asbestos cases that are not flagged as "superceded," I'm fine with that.

Comment [s9R7]: Ok, we'll keep it. Since its so recent and there aren't any other sources. 
patient could not show causation between a failure to warn and the injury of dementia if the patient could not have prevented the dementia from developing.

If the causation question hinges on the facts of the particular case (such-such as in the case of whether Christian Williams would have been treated differently had the VUS been classified as Dravet-causing ${ }^{168}$ - then the judge should typically let the jury decide whether this satisfies the element of causation. 169 At least one court has recognized that incomplete information about penetrance and the potential success of treatment can foreclose summary judgment.170 In Safer v. Estate of Pack, New Jersey's superior court stated:

we are led to understand from the experts' reports that the risk of multiple polyposis was significant and that, upon detection, an early full colectomy, i.e., an excision of her entire colon, may well have been the treatment of choice to avoid resultant cancer-including metastasis, the loss of other organs and the rigors of chemotherapy. Full factual development may, however, cast a different light on these issues of fact and others. 171

Because causation in this particular case could not be proved, the case went to trial.172

As a class, plaintiffs might argue that a laboratory's failure to warn caused them to miss out on a chance of a good clinical prognosis. But if a plaintiff complains of wrongful death instead of a "lost chance," then courts are more likely to find there was no duty to warn. The "lost chance" theory first emerged in cases where defendants had duties to rescue someone that stood in a close, special relationship to them. 173

In a minority of states the theory of lost chance operates to relax the standard of causation, where the plaintiff can receive compensation even where it is not possible for the plaintiff to prove that she would have probably survived in absence of the defendant's breach.174 But this is thought of as an "extreme" position.175 In most states, the "lost chance" theory reframes the injury and

\footnotetext{
${ }^{168}$ Jennifer K. Wagner, Litigating the Accountability of Clinical Genomics Laboratories, GENOMICS L. REPT. (May 31, 2016), https://www.genomicslawreport.com/index.php/2016/05/31/litigating-theaccountability-of-genomics-laboratories/.

169 Id.

170 Safer v. Estate of Pack, 291 N.J. Super. 619, 628, 677 A.2d 1188, 1193 (N.J. App. Div. 1996).)

171 Id.

172 Id.

173 The Fourth Circuit held that "this view ignores the underlying character of the duty. It was less than a duty to rescue him, but it was a positive duty to make a sincere attempt at rescue. The duty is of such nature that its omission will contribute to cause the seaman's death. The duty arises when there is a reasonable possibility of rescue. ...[t]herefore, proximate cause here is implicit in the breach of duty." Gardner v. Nat'l Bulk Carriers, Inc., 310 F.2d 284, 287 (4th Cir. 1962).

174 J. Stephen Phillips, The "Lost Chance" Theory of Recovery, Colo. Law. 85-86 (1998); "In medical malpractice cases involving preexisting medical conditions, a majority of jurisdictions have declined to relax the standard of causation or create a new compensable injury." Lisa Perrochet, Lost Chance Recovery and the Folly of Expanding Medical Malpractice Liability, 27 Tort \& Ins. L.J. 615, 628 (1992). 175 See DeBurkarte v. Louvar, 393 N.W.2d 131, 137 (Iowa 1986) (“'This position] effectively allows a jury to speculate on causation because expert testimony that a physician's negligence probably caused the total damages is not required. This is an extreme position and clearly distorts the traditional principles of causation."); see also Alice Férot, The Theory of Loss of Chance: Between Reticence and Acceptance, 8
} 
compensates the degree to which the chance of survival was lost, as opposed to compensating the injury itself.176 Courts typically only allow the "lost chance of survival" claim if the defendant breached a duty to fail to rescue someone he or she should have or committed medical malpractice resulting in the plaintiff's death. 177

Because imposing a duty to rescue departs from traditional common law, it is narrowly circumscribed. Most defendants do not owe a duty to rescue or warn plaintiffs in the absence of a pre-existing, special relationship with the plaintiff.178 Again, it is the physical custody, fiduciary obligation, and vulnerability of the plaintiff vis-à-vis the defendant that imposes a duty to rescue upon the defendant.179 For example, a ship master should at least attempt to rescue one of his seaman because no one else could rescue him and he was put at risk by the ship master's enterprise.180 Once again, this duty is limited to rescuing from imminent physical injury, and courts do not automatically analogize from a duty to rescue to a duty to warn.181 While a duty to rescue is far more burdensome than a duty to warn, the risk of imminent physical injury motivates each duty.

Courts are disinclined to impose affirmative duties to rescue or warn if the plaintiff cannot prove that the defendant's inaction probably caused the plaintiff's injury and the plaintiff did not share a special relationship with the defendant.182 Courts adhere rigidly to the typical burden of proof with each element because not every injury requires compensation from tort law. Some injuries are too intangible and distant from defendant's actions to impose tort liability. Simply that an injury may be prevented does not mean the defendant owes a duty to prevent it. 183 The plaintiff must prove that the defendant's failure to warn was a probable - not just a possible - cause of plaintiff's injury. 184

F. INT'L U. L REv. 591, 593-94 (2013) [hereinafter Férot] ("Professor King, however, formulated the theory of loss in chance in terms of causation and burden of proof, not in terms of injury.... The loss of chance is not a theory of causation but a theory of injury.").

176 Watson v. Glenwood Reg'l Med. Ctr., 163 So. 3d 817, 822 (La. Ct. App. 2015) ("The loss of chance of survival is a distinct compensable injury caused by a defendant's negligence, distinguishable from the loss of life in wrongful death cases...In short, the lost chance is a separate and valuable claim or element of damages, not a distinct cause of action that may accrue later than the initial act of malpractice."). 177 Pelas v. Golden Rule Ins. Co., 1999 WL 438478, at *2 (E.D. La. June 28, 1999)(“In limiting recovery to medical malpractice cases, the Hardy court emphasized the need to restrict the application of the relaxed burden to special circumstances such as the patient-physician relationship." Id. at *9 quoting Hardy v. Southwestern Bell Tel. Co., 910 P.2d 1024, 1029 (Okla. 1996)); See also, Férot, supra note 165, at 592 ("In the United States, the theory of loss of chance has been implemented mostly in the area of medical malpractice. Usually, a patient, or his or her representative, will sue a healthcare provider for a failure to diagnose or a failure to cure a medical condition that resulted in the diminution of the patient's chance to survive or recover from the condition.").

178 Groninger, supra note 60 , at 359 .

179 See id. at 358

180 See id. at 360.

$181 \mathrm{Id}$. at 360.

$182 \mathrm{Id}$.

183 See id. at 356.

184 See Owen, supra note 58, at 1671. 
The plaintiff would have a much stronger claim against the laboratory if the plaintiff suffered a concrete, materialized physical injury can prove, by a preponderance, of the evidence, that the laboratory caused her injury by failing to warn her of the SF. To the extent a plaintiff alleges "lost chance" of a better outcome and cannot prove that her injury would have been averted if the lab had given her the SF, the plaintiff would lose in most states. In our case the patient is already exhibiting symptoms of another disease that is warranting the genetic test. Proving that delayed diagnosis of an SF caused a significant lost chance is difficult, though not impossible. A plaintiff could easier prove causation if the SF is linked to a more serious disease than the disease for which the patient initially sought treatment. Some states limit the "lost chance" theory of injury to traditional medical malpractice where the defendant-physician breached a standard of care by failing to make an important diagnosis. 185 Thus, if the plaintiff is suing in one of those states, the injury could not be framed as lost chance of a better outcome.

\section{d. The Fourth Factor: The Moral Blame Attached to Defendant’s Conduct}

The moral blame attached to a laboratory for failing to return SFs or VUS is not as intense as the blame attached to someone who fails to warn of imminent, physical injury. Moral blame is particularly fascinating as applied to tort law. The history of tort law is checkered when it comes to liability being connected to moral blame.186 The law can hold employers liable for the actions of their employees, even when they are not at fault in supervising them.187 Similarly, the law might hold those with mental illness liable, even where it is impossible for them to conform their conduct to the standard tort law requires.188 Indeed, much of tort law has very little to do with moral wrongfulness. But when it comes to expanding liability for the unexpected, courts return to the moral blameworthiness of the inaction as a touchstone to determine whether a duty to warn exists. 189

It is not easy to assess blame in the abstract, because we tend to impose blame somewhat irrationally and based largely upon outcome. For example, in the abstract people probably do not expect a laboratory to return SFs or VUS, and so long as no one is injured, people will not find that the laboratory was blameworthy for failing to return these results. But if someone suffers injury, even if the injury was not foreseeable, people tend to attribute blame and intentionality to the same previously blame-free decision. If the defendant is sued and could have prevented the delayed diagnosis, people will attribute some culpability to its decision not to warn. Even if the actor did not anticipate the bad outcome, outcome matters a great deal.190 This effect seems to

185 Misdiagnosis and Failure to Diagnose, JUSTIA, https://www.justia.com/injury/medicalmalpractice/misdiagnosis-and-failure-to-diagnose/ (last visited March 13, 2018).

186 See generally Christopher Jackson, Tort, Moral Luck, and Blame, 60 CLEV. ST. L. REV. 57, 58

(2012).

187 Russel G. Thornton, Responsibility for the Act of Others, 23 BAYLOR UNIV. MED. CTR. PROC. 313, $313(2010)$.

188 William J. Curran, Tort Liability of the Mentally Ill and Mentally Deficient, 21 OнIо ST. L. J. 52, 52 (1960).

189 Thomas J. Murphy, Affirmative Duties in Tort Following Tarasoff, 58 St. John's L. Rev. 492, 527

(2012).

190 Mark D. Alicke, Blaming Badly, 8 J. Cognition And Culture 179, 181 fn. 1 (2008) (“Intentionality judgments are, therefore, susceptible to outcome bias, which involves judging an outcome in terms of its 
work only in one direction, humans blame those who accidentally cause harm and attribute intentionality to their actions, but do not praise those who accidentally cause a benefit. This is the "praise/blame asymmetry" or the "Knobe effect."191 And it has an impact on tort law.

As tort scholars Goldberg and Zipursky note, there is a certain amount of luck that factors into liability: the careless actor who happens not to injure someone pays nothing, but the careless actor who unluckily injures someone pays a great deal.192 The law of negligence disproportionately punishes those who happen to get unlucky when they are careless and infers bad intent or blameworthiness to their actions even when there was none. This common practice, and its underlying moral philosophy, suggests that jurors will find the laboratory morally blameworthy if they knew an SF was pathogenic and treatment was available and it failed to warn the patient, even if penetrance was low and expression was variable. Or the laboratory could be considered morally blameworthy if it knew the SF related to a severe drug reaction and did not pass that information along to the patient because the laboratory believed it quite unlikely that the patient would ever need the drug. If the patient ever needed the drug, the laboratory may have believed that a physician would order the relevant genetic test. A less likely, but potential scenario would involve a case like the Williams', where a laboratory designated a mutation of "unknown significance," and the pathogenicity of the mutation was ambiguous.193 If in hindsight the mutation proved to be pathogenic, a jury might infer moral blameworthiness to the lab who legitimately designated the mutation as VUS. But placing blame on the defendant probably only occurs when the plaintiff suffers significantly from the non-disclosure.

Because assessing duty and blame should be decided more abstractly and should apply to many cases with different facts, it seems unlikely that the laboratory would be thought of as morally blameworthy for failing to warn patients of unforeseeable harms. The plaintiff can make a stronger case for moral blameworthiness if the laboratory does not share the SFs with the ordering physician it knows to be pathogenic and treatable. Even that failure, however, is less blameworthy than the failure to warn readily identifiable victims of imminent physical violence. If any moral blame exists, it is a small dose aimed at the physician who failed to share the results with his or her patient. It is aimed less at the lab who failed to share results directly with the patients. Imposing moral outrage or blame on the lab's breach results from the Knobe effect.194

Empirical data can provide a sense intuition about the laboratory's obligations and likely correlates to how blame would attached for failure to meet these obligations. When surveyed, $67 \%$ of genetics professionals believed that health-care providers have an obligation to return positive

consequences, independent of the decision-maker's intentions and the causal process by which they were generated.").

191 The praise/blame asymmetry is widespread; it holds for 4 year olds, Hindi-speakers, and people with emotional deficits. See, Frank Hindriks, Normativity in Action: How to Explain the Knobe Effect and its Relatives, 29 MIND AND LANGUAGE, 51, 53 (2014).

192 John C.P. Goldberg and Benjamin C. Zipursky, Tort Law and Moral Luck, 92 CORNELL L. REV.

1123, 1132, 1135 (2007).

193 See Williams v. Quest Diagnostics, 2014 Okla. Dist. LEXIS 394 (7th Dist. Oct. 24, 2014).

194 Joshua Knobe, Intentional Action and Side Effects in Ordinary Language, 63 ANALYSIS 190, 194

(2003). 
SFs from clinical-exome sequencing or whole-genome sequencing for Mendelian diseases.195 Sixty-one percent thought they should disclose SFs of negative-drug interactions, $49 \%$ thought they should disclose carrier status, $20 \%$ thought they should disclose complex traits, and $25 \%$ thought they should not disclose any SFs.196 This population is biased because they are sophisticated genetics professionals as opposed to lay patients or plaintiffs who would receive the information. 197 Nevertheless, focus-group studies indicate that most non-African- American participants would want "actionable" genetic-WGS results yielding benefits such as medical treatment or disease prevention, and "expect and are motivated by the ability to use individual genetic information for future planning."198 While some participants self-identified as "planners" who want more information for the sake of family-reproductive planning, this was not a universal response.199 Some participants did not want to know results with likely false-positives or falsenegatives because it would "cloud" their thinking, might be "too big, too scary" and such results might be "paralyzing."200 These lay-people perspectives render non-disclosure much more morally ambiguous, at least in the abstract and ex ante.

The nature of the conveyed information renders non-disclosure much less morally blameworthy than where courts have imposed a duty to warn. Namely, a therapist who fails to inform a potential victim that one of his patients is targeting the potential victim more morally blameworthy, as is a homeowner who fails to warn a guest of a sharp piece of broken porcelain. These cases are unambiguous in terms of their moral valence, given the magnitude of the risk of non-disclosure as compared with the risk of unnecessarily worrying the victim. With the return of SFs, the risk is more equivocal because there is a possibility of future harm from non-disclosure, but also a possibility of harm from disclosure, and the risk is sometimes much less imminent. The harm of disclosure is greater relative to the harm of non-disclosure. Because the would-be patients disagree about whether they ought to have this information communicated to them, the tort "duty to warn" stands on a shaky moral ground.

\section{e. The Fifth Factor: The Policy of Preventing Future Harm}

The policy of preventing future harm is the next Rowland factor. While not every preventable harm imposes a tort obligation to do so, this factor weighs into the calculation. It relates to the other factors of foreseeability, moral blame, and causation. But rather than looking at particular cases and arguing whether a warning could prevent harm in a specific instance, the "policy" factor considers the abstract public-policy perspective and looks at net harms prevented. . The question becomes whether the policy of imposing a duty to warn in general and on average-

$195 \mathrm{Yu} 2014$, supra note 31 at 79.

$196 \mathrm{Id}$. at 84.

$197 \mathrm{Id}$. at 77

198 Joon-Ho Yu, et al., . "Attitudes of Non-African American Focus Group Participants Toward Return of Results from Exome and Whole Genome Sequencing, 95 AM J. HUMAN GENETICS 2153, 2157 (2014) [hereinafter $\mathrm{Yu}$.

199 Id. at 5-6.

$200 \mathrm{Yu}$, supra note 192 , at 2156. 
When it comes to disease-causing SFs, there is a good, but weaker claim for disclosure on prevention grounds. It might be difficult to prove that a patient would have pursued a different treatment had she had known about her SF or that the non-disclosure caused her injury. Tort law could only remedy realized injuries from a delayed diagnoses, such as medical expenses and a premature death, that could be averted. The risk of false positives and false negatives are significant, and could lead to unnecessary psychological stress in the case of false positives or unwarranted relief in the case of false negatives. But in the aggregate, knowledge of SFs would lead to better clinical outcomes if the patient can recall the SF when necessary. Despite the significant risks of false positives and false negatives - and the possibility of psychological stress or false assurances - the more concrete harm is the injury from a delayed diagnosis, such as medical expenses and a premature death, that could be averted. And it is this injury which could be prevented by requiring labs to disclose clinically actionable SFs.

Again prevention of future harm depends on the type of duty alleged. In terms of prevention, the case for disclosing adverse-drug genotypes is perhaps the strongest, given that the patient might be offered a drug, she could refuse, given with knowledge of her a SF. It might not be foreseeable that she would ever need the particular drug, but there is a strong argument that had she been told of this particular SF, she could have avoided a serious reaction if she ever needed the drug in the future. But this assumes that the patient would remember the SF and recall it when offered that drug in the future. It assumes that her physician would have entered the SF into her medical record for future use. Both of these situations are plausible, if not certain. Many of serious adverse drug events could be prevented if patients were warned of their SFs.

While the ACMG does not recommend returning pharmacogenomics SFs,202 laboratories may have a greater tort duty to warn of potentially fatal drug side effects that could be predicted by someone's genetics because of the improved ability to prevent a concrete harm. Even though the foreseeability of harm varies based on penetrance and the complexity of genetics, some single, rare mutations predict severe drug reactions, as discussed above.203 When a laboratory knows of these mutations, and the individual takes the proscribed drug, the foreseeability of harm is likely and could lead to death.204

This still assumes that laboratories would share the information in a way that makes sense to the patient, that the patient remembered it, and could recall it when necessary. Even so, because these plaintiffs could demonstrate that they would have remembered their SF and would have done something different regarding their health, they can show that disclosure would prevent future harm. The disclosure of information could be used in many clinical ways that are quite thoughtful

202 Orli G. Bahcall, ACMG Guides on the Interpretation of Sequence Variants, 16 NATURE REV. GENETICS 256, 256 (2015).

203 Sources cited supra notes 138-141. (HIV and HLBA).

204 Zhang, supra note 132, at 76. 
and deliberate, including future generation's reproductive planning.205 It is therefore possible to say that knowledge of the SF could prevent aggregate future harms from delayed diagnosis or drug interactions. Indeed, this factor might favor return of SFs than it was in Rowland and Tarasoff.

Empirical data published following the Tarasoff case demonstrated that this factor could have made the court move in a different direction.206 Therapists are not particularly good at predicting when violence is imminent, and given the nature of the risk-serious physical violence, which could occur at any time - a warning does not usually prevent the harm.207 Even if Tatiana Tarasoff had been warned of her murderer's plot, short of staying home on house arrest for her life, the warning could not have kept her murderer away. This strikes a huge blow to imposing duty and calls into question the plaintiff's ability to prove causation. If a warning will not prevent harm, then imposing a duty may be motivated too much by moral outrage and a desire to hold someone accountable, rather than on typical negligence grounds.

\section{f. The Sixth Factor: The Potential Resource Burden on Labs}

Many of the Rowland factors mimic the rubric the ACMG working group used to determine which SFs laboratories should routinely disclose. 208 This is not surprising, because the elements of negligence mirror cost-benefit assumptions about how we should hold those who engage in careless behavior accountable. But there is a key difference between the ACMG criteria for disclosure and the Rowland criteria. Tort law recognizes that while there might be an ethical obligation to warn, there might not be a legal one if the burden of warning is too great.209 Courts should consider whether imposing this duty will cost the defendants too much time or money, relative to the risk being prevented.

If the duty to warn is framed in terms of merely having to provide the ordering physician with clinically actionable, validated pathogenic SFs that were already analyzed, along with some basic interpretive information, this is not likely to be too burdensome. Indeed, courts will likely see this burden as commensurate with any preventable risk, given that the burden is merely passing along already-gathered results. 210 This is analogous to asking a physician to report an incidental finding of a liver tumor the physician detected when he or she ordered a stomach X-ray. To reduce the risk of undue psychological distress on the patient, the physician must then place the results in context, including for the patient. This includes communicating with the patient the need for confirmation testing. In the context of genetic sequencing, it would be inappropriate for the laboratory to assume a duty to place the results in context for the patient whom they have never met and likely never will because the laboratory has no special relationship with the patient. Thus,

205 If the claim is "lost chance to terminate a pregnancy" courts are much less willing to entertain this claim than if it is framed as a "lost chance to employ genetic screening devices" to select particular embryos for implantation. Simmons v. W. Covina Med. Clinic, 260 Cal. Rptr. 722, 776-77, (Ct. App. 1989).

206 Toni Pryor Wise, Where the Public Peril Begins: A Survey of Psychotherapists to Determine the

Effects of Tarasoff, 31 STANFORD L. REV. 165, 186-187 (1978); Douglas Mossman, The Imperfection of

Protection Through Detection and Intervention, 30 J. LEGAL MED. 109, 133 (2009).

207 Wise, supra note 202, at 187; Mossman, supra note 202, at 133.

208 Kalia, supra note 39, at 249.

209 Peter CANe, Atiyah's ACCidents, Compensation, AND the Law, 74 (2013).

210 See Davis v. Wyeth Lab., 399 F.2d 121 (9th Cir. 1968). 
if framed in terms of needing to disclose SFs to the ordering provider, there is a good case for this duty to be imposed, assuming that the risk of harm is foreseeable and significant.

If, however, the lab is expected to: investigate public or medical records to find contact information for the patient, to contact the patient and reveal the presence of the SF, to follow-up with clinical referrals, to pay for additional sequencing methods to confirm the presence of the SF, to request samples from the patients and then test those samples to determine the spontaneity of the mutation, to run contemporaneous literature-review searches after every test to ensure current classifications of SFs, then these are too great of burdens to impose. Like all of the Rowland factors, this evaluation is a judgment call. Courts could reach different conclusions, depending on how they weigh the benefits of prevention and the burdens of disclosure. But if courts take seriously the balancing of benefits and costs of imposing this duty and consider early duty-to-warn cases, courts should not impose any duty on a laboratory to directly contact patients with clinically ambiguous SFs.

Some labs voluntarily undertake to do more than what the law requires as industry standards evolve.211 But as more patients submit samples for WES or WGS, the frequency of these scenarios will be too great for laboratories to incur their cost. Laboratories test patients and run ad hoc literature reviews on genetic tests because the volume is not too great.212 But this will not be scale-able, absent future insurance reimbursement for this sort of task.

\section{g. The SeVenth Factor: The Lack of Insurance to Spread the Cost of Imposing a Duty}

The Rowland court included a final factor that assessed the cost, prevalence and availability of insurance to mitigate the risk.213 If the defendant could purchase insurance-say, such as renter's insurance as Christian did in the Rowland case itself, or medical insurance in malpractice cases - to absorb some of the cost of resulting injuries, courts should be more inclined to impose a duty.214 But if a considerable portion of the injury comes from pain and suffering damages that the plaintiff cannot cover through insurance or if there is no real way of limiting the defendant's exposure, then this factor mitigates against imposing a duty. 215 If the potential for liability is too vast, then the burden on defendants will be too great to justify. The few courts to directly address this factor have emphasized that the liability must have some limits, so that defendants do not become bankrupt and are not "priced out" of buying insurance in the future. 216

If clinical laboratories have a duty to warn patients of SFs, it is unclear who would pay for this burden and the resulting injuries upon breach of that duty. Currently, clinical laboratories likely do not have adequate liability insurance to cover the cost of failure-to-warn lawsuits. This

211 FIND Source

212 Lidia Feliubadolo, et al., Benchmarking of Whole Exome Sequencing and Ad Hoc Designed Panels for Genetic Testing of Hereditary Cancer, SCI. REP. (Jan. 4, 2017).

213 Rowland, 443 P.2d at 568.

214 Id. at 567-68.

215 See Kesner v. Superior Court, 226 Cal. App. 4th 251, 261 (Cal. Ct. App. 2014) superceeded by Kesner v. S.C. (Pneumo Abex LLC), 331 P.3d 179 (Cal. 2014), and vacated, Kesner v. S. C., 384 P.3d 283 (Cal. 2016).

216 See Kesner v. S. C., 384 P.3d 283, 296 (Cal. 2016).

Comment [s10]: I understand that you don't have a source for this. Can you say something to the effect of: This is based on my conversations with individuals from XXX laboratories over the course of my research? 
is a new conception of a legal duty, likely not built into existing policies. If courts impose this duty, insurance markets might begin to provide this coverage, but involve difficult market pricing whole-exome sequencing is only just beginning in the clinical sphere. Liability exposure could be vast if damages extend beyond SFs likely to cause foreseeable, severe harm. Of course, a first-ofits-kind high profile case with a pediatric patient who was killed, due to unreported SFs, and who might not have been had the lab reported different data, might be enough to steer this litigation in the wrong direction. While courts have imposed liability on laboratories for mishandling or improperly classifying results or omitting key findings, the return of SFs presents a novel duty that insurance providers have not yet assessed.

This factor covers insurance to cover the defendant industry's liability. But given the role that the plaintiff's medical-insurance plays in reducing the financial cost of compliance for defendants, it is worth mentioning how insurance covers genetic tests, which could also have been analyzed under the previous factor "burden on defendants." Insurance coverage for WES and WGS is spotty. 217 Even when patients have positive-disease symptoms and look for a related genotype, insurance coverage for genetic tests is "uncertain." 218 The billing director for Ambry Geneticsthe first commercial lab to offer whole exome sequencing - said insurance coverage is "all over the map." 219

Genetic tests are sometimes paid for as part of an inpatient hospitalization when patients have a debilitating disorder and are looking for the genetic cause. 220 Genetic testing for a present disorder is paid partly by insurance and partly by the patient. If the patient is an outpatient, in some cases, the ordering physician chooses the clinical laboratory based on "out-of-pocket expense to patients by comparing the costs between laboratories based on patients' insurance.”221

The argument for insurance coverage is greater when someone is on a diagnostic odyssey, because present clinical need motivates the test. In our case, paying for follow-up tests to assess the clinical validity of a potentially significant SF has a much more attenuated connection to present clinical care. Therefore, insurance is even less likely to cover it. As a senior medical director for Aetna insurance stated in 2014, some of whole-genome sequencing is still in the "early stages" of analytic and clinical validity.222 Currently, the lack of standards on ensuring quality control, interpreting, and validating results makes it unlikely private insurers will cover this

217 Cigna Issues Coverage Criteria for Whole-Exome Sequencing; WGS Still Not Covered, GENOME WEB (Nov. 23, 2015), https://www.genomeweb.com/sequencing-technology/cigna-issues-coveragecriteria-whole-exome-sequencing-wgs-still-not-covered.

218 David Bick, et al., Successful Application of Whole Genome Sequencing in a Medical Genetics

Clinic, 6 J Clinic PEDIATR Genet 61, 762017.

219 See Steenhuysen, supra note 15.

220 Coverage and Reimbursement of Genetic Tests and Services, Report of theSecretary's Advisory

Committee on Genetics, Health, and Society, available online at

http://www4.od.nih.gov/oba/sacghs/reports/CR report.pdf, at p. A6 (2006).

221 Alejandro Iglesias, et al., The usefulness of whole-exome sequencing in routine clinical practice, 16 GENETICS IN MED. 922, 931 (2014).

222 Will Insurance Cover Genome Sequencing?, GENEWATCH,

http://www.councilforresponsiblegenetics.org/genewatch/GeneWatchPage.aspx?pageId=440 (last visited Mar. 13, 2018) [hereinafter GeneWatch].

Comment [s11]: I know this from personal conversations with ARUP lab folks. I didn't have a good source for this, but we could cite to this report, which highlights that federal law must cover inpatient labs for Medicaid recipients. It's a little old but still accurate.

Comment [s12R11]: Can you make the footnote to say that you've spoken to individuals through the course of your research?

Comment [s13R11]: 
test.223 Medicare does not.224 While some insurance companies - even Medicaid - may initially cover genetic testing for patients on diagnostic odysseys, this is due to the low volume of requests. 225 Scant private coverage subsidized the many claims insurers denied. But "[a]s use of the new technology has grown, a number of insurers, including Blue Cross Blue Shield, have reacted by putting the brakes on reimbursement."226 Dr. Allen Bale is the director of the DNA Diagnostic Lab at Yale School of Medicine. Since 2011, he has seen a 500 percent increase in orders for exome sequencing, and likely more.227

Two major health plans have started developing policies for future coverage, but at currently deny most requests due to the "experimental and unproven" nature of WES and WGS.228 As with all insurance coverage decisions, future coverage depends on the extent to which the results of the testing are analytically and clinically valid and clinically actionable.229 If the information translates into a "measured improved health outcome," insurance will more likely cover these tests.230 But insurers will probably restrict coverage for WES and WGS to "patients with disorders of suspected genetic etiology but no obvious diagnosis," and "patients with a suspected diagnosis that could involve one or more genes."231 So insurance will not routinely cover the cost of a follow-up test to confirm the presence of an SF because it is not pursued due to a present health disorder.232 Without a test to confirm existence of an SF, the SF may not be clinically actionable due to the poor analytic validity of WES and WGS.

The absence of adequate liability insurance, the potential for vast liability for intangible harm, and the unavailability of reimbursement from the plaintiff's health insurance mitigate against imposing a duty to warn on laboratories. While future laboratory professional insurance might cover this litigation, it is the present availability of insurance that matters. If imposing a duty requires insurance coverage to expand, this suggests the duty is too burdensome and does not respond to a foreseeable and presently insurable risk.

\section{To WhOm Would The Duty Be Owed?}

223 Id.

224 Dylan Scott, Calls Intensity to Get Medicare to Pay for Genetic Sequencing Tumors, STAT (Jan. 26, 2016), https://www.statnews.com/2016/01/26/gene-sequencing-medicare-tumors/.

225 Konstantinos N. Lazardis, et al., Outcome of Whole Exome Sequencing for Diagnostic Odyssey Cases of an Individualized Medicine Clinic: The Mayo Clinic Experience, 91 Mayo Clinic Proceedings 297, 297 (2016).

226 See Steenhuysen, surpa note 15 ("'[I]nsurance companies initially paid for most of the tests, but as volume has increased, more claims are getting denied. "There are some companies that are saying out and out, we won't cover this test.").

227 See id.

228 See The Future of Genomic Medicine: Policy Implications for Research and Medicine, NAT'L HUMAN GENOME RESEARCH INST. (Nov. 16, 2005),

https://www.genome.gov/17516574/the-future-of-genomic- medicine-policy-implications-for-researchand-medicine/.

229 Steenhuysen, supra note 15.

230 GeneWatch, supra note 223.

231 See id.

232 See id. 
Even if the law imposed a duty to warn on laboratories, to whom would the laboratory owe a duty? While the precise individual need not be named, courts have limited the duty to warn to "readily identifiable" individuals.233 In Thompson v. County of Alameda, a juvenile delinquent murdered a child after his release from a county-correctional facility. 234 The victim's parents brought a wrongful death action, claiming that the county should have warned them, the local police, or "parents... within the immediate vicinity of the juvenile's residence" of a potentially violent offender's release. 235 The court found that the county did not have a duty to warn these groups because "the duty to warn depends upon and arises from the existence of a prior threat to a specific identifiable victim." 236 In this case, the juvenile delinquent's threats were non-specific and generalized and the court declined to impose upon the county an affirmative duty to warn such a "large amorphous public group of potential targets."237 Many state courts have agreed, requiring specific threats against readily identifiable victims before a duty arises.238 As one Ohio court put it, "the 'readily identifiable victim' rule is born, lives, and grows in failure-to-warn cases."239And a Minnesota court further clarified that the "duty to warn is not owed to statistically probable victims, but rather to specifically targeted victims." 240 A Florida court extended the duty to a third party where the court - in evaluating the risk of genetic disease - found that where a physician's obligations runs to people other than the patient and the physician "knows of the existence of those third parties, then the physician's duty runs to those third parties." 241

While some courts require that the perpetrator specifically name the intended victim to impose a duty to warn them, not every state follows this law.242 But the courts hold firm to the concept of foreseeability; the narrow class of persons to be warned must be foreseeable, and reasonably identifiable, even if the ultimate plaintiff has not already been individually identified.243 Thus, in Alaska the high court wrote that "we see no reason to predicate liability wholly on the state's ability to predict the victim's name. A victim may be 'foreseeable' without being specifically identifiable."244

233 Emerich, 720 A.2d at 1040.

234 Thompson v. Cty. Of Alameda, 614 P.2d 728, 738 (Cal. 1980).

$235 \mathrm{Id}$. at 730 .

236 Id. at 738 .

237Id. at 728. Thompson v. Cty. of Alameda, 27 Cal. 3d 741, 758, 614 P.2d 728 (1980)

238 Allison L. Almason, Personal Liability Implications of the Duty to Warn Are Hard Pills to Swallow: From Tarasoff to Hutchinson v. Patel and Beyond, 13 J. CONTEMP. HEALTH L. \& POL'Y 471, 479 (1997) see Sheerin v. State, 434 N.W.2d 633, 636 (Iowa 1989); Rogers v. S.C. Dep't of Parole \& Cmty. Corr., 464 S.E.2d 330, 332 (S.C. 1995); Morton v. Prescott, 564 So. 2d 913, 916 (Ala. 1990); Bradley v. Ray, 904 S.W.2d 302, 307 (Mo. Ct. App. 1995); Leonard v. Latrobe Area Hosp., 625 A.2d. 1228 (Pa. Super. Ct. 1993); Peck v. Counseling Serv., 499 A.2d 422 (Vt. 1985); Bardoni v. Kim, 390 N.W.2d 218, 307 (Mich. App. 1986).

239 See Estates of Morgan v. Fairfield Family Counseling Ctr., 77 Ohio St. 3d 284, 310, 673 N.E.2d 1311, 1331 (Ohio 1997).

240 Cairl v. State, 323 N.W.2d 20, 26 (Minn. 1982).)

241 Pate v. Threlkel, 661 So. 2d 278, 282 (Fla. 1995). )

242 See Limon v. Gonzaba, 940 S.W.2d 236, 239 (Tex. App. 1997)

243 James v. Wilson, 95 S.W.3d 875, 891892 (Ky. Ct. App. 2002). )

244 Div. of Corr., Dep't of Health \& Soc. Servs. v. Neakok, 721 P.2d 1121, 1129 (Alaska 1986)

superseded by State, Dep't of Corr. v. Cowles, 151 P.3d 353, 363 (Alaska 2006). 
Courts have applied the same reasoning outside of the context of warning of violent offenders. In a case where the plaintiff claims the defendant should have warned plaintiff that having sex with his wife - who was having an affair with defendant — could lead him to acquire a sexually-transmitted disease, the court found that a spouse was a foreseeable plaintiff and so a duty to warn was created.245 But the court cautioned that the law will not impose liability on a defendant related "to any and all persons with whom she may have sexual contact."246 The duty to warn extends only to those individuals who are reasonably foreseeable.

In the context of SF or VUS, this suggests that laboratories should not have to spend a great deal of time or resources identifying the patients or relatives of patients. While the phrase "readily identifiable" is sufficiently ambiguous, it is likely that courts will require laboratories to identify someone at risk who is commensurate with the risk. While courts are willing to impose greater burdens on defendants to warn third parties of imminent, physical violence, courts are not as likely to require laboratories to re-contact the patient for the telephone numbers and names of the patient's relatives, as related to a non-imminent risk. Would the lab need to search the family history records of the patient to find contact information for relatives? This also seems to require too much legwork to be considered "readily identifiable," given that the law would expect the laboratory to do this for every person who submits a tissue sample and receives an SF.

\section{Patient Confidentiality Should Not Be BReached When There is No Risk of Imminent} PHYSICAL ViOLENCE

Because of patient privacy - protected through the common law and state and federal statutes like HIPAA - the laboratory must ensure that if they disclose SFs to patients or relatives, it does not violate the patient's privacy or confidentiality.247 One early court who dealt with the duty to warn of heritable diseases, transferred the duty to the patient.(in genetics, the reference patient is called the "proband.") 248 In Pate v. Threlkel, the court found that the provider discharges his duty to warn non-patients through informing the proband -with a recommendation that he pass the risk information along to the at-risk third party.249 Because "the patient ordinarily can be expected to pass on the warning," the physician does not need to tell the third-party relatives themselves of a genetic mutation.250 In so holding, the court instructed that requiring physicians to:

seek out and warn various members of the patient's family would often be difficult or impractical and would place too heavy a burden upon the physician. Thus, we emphasize that in any circumstances in which the physician has a duty to warn of a genetically transferable disease, that duty will be satisfied by warning the patient. 251

245 Mussivand v. David, 544 N.E.2d 265 (Ohio 1989).

246 Id. at 273.

247 US DEP'T OF HEAlth \& Human, Summary of the HIPAA SECURITY RULE,

https://www.hhs.gov/hipaa/for-professionals/security/laws-regulations/index.html (last updated July 26, 2013).

248 Pate v. Threlkel, 661 So.2d 278 (Fla. 1995).

249 See Pate, 661 So.2d at 282 (holding that a duty to warn patient of condition that could be passed on to daughter).

250 Id.

251 Id.

Comment [s14]: Be consistent with this term. You later switch away from using it.

Comment [MOU15R14]: Please conform all references that you think should be proband.

Comment [s16R14]: I've changed where I thought was applicable and to make it clearer. 
Of course, this makes several inappropriate assumptions. First, it assumes that the family dynamics are healthy and that communication lines are open. Second, it assumes that the proband will correctly pass along the information, with the appropriate clinical suggestions for follow-up. But in some families, the proband cannot be expected to accurately pass along the warning. 252

In Safer v. Estate of Pack, the New Jersey court analogized imposing a duty to warn of genetic risks to a duty to warn of serious infectious diseases.253 Safer held that while imposing broad duties to non-patients might lead to confusion or unfairness, in the case of warning of "avertible risk from genetic causes, by definition a matter of familial concern" is narrow enough to be workable and just. 254

The court further held that the "duty "extend[s] beyond the interests of a patient to members of the immediate family of the patient who may be adversely affected by a breach of that duty." 255 In Safer, the duty to the non-patient relative was considered discharged by informing the patient of the risk, and assuming that the patient would share this information with his relative. However, the court reserved the possibility of one day breaching a proband's confidentiality to warn a nonpatient, if there were some indication the patient would not tell their relative. 256

Whether breaching a patient's common-law confidentiality protections is justified requires the law to balance interests.257 Recall that in Tarasoff, the defendant-psychotherapist did not further warn Tatiana Tarasoff because he feared breaching his patient's right to privacy.258 The court famously stated that "the public policy favoring protection of the confidential character of patient-psychotherapist communications must yield to the extent to which disclosure is essential to avert danger to others. The protective privilege ends where the public peril begins." 259 Thus, when it comes to the duty of psychotherapists to warn third-parties, the law should balance

252 Studies have found that positive test results are more likely to be disclosed than negative or uninformative results. White females, who have a higher income, and have a personal history of cancer, are more likely to disclose genetic test results with family members. Probands are also more likely to share their results if they perceive that relatives are emotionally ready and able to understand the information, they are close with the relative, and they think it will help their relative's clinical decision-making. In terms of psychological factors, probands are also more likely to share results with family if they report greater self-efficacy for health management and less fatalism over cancer prevention. See Kelly Kohut, et al., Should Healthcare Providers have a Duty to Warn Family Members of Individuals with an HNPCCcausing Mutation? A Survey of Patients from the Ontario Familial Colon Cancer Registry, 44 J. MED. GENETICS 404, 405 (2007).

253 Safer, 667 A.2d at 1192 ("In terms of foreseeability especially, there is no essential difference between the type of genetic threat at issue here and the menace of infection, contagion or a threat of physical harm. The individual or group at risk is easily identified, and substantial future harm may be averted or minimized by a timely and effective warning." (internal citations omitted)).

$254 \mathrm{Id}$.

$255 \mathrm{Id}$

256 Id. at 1192,93 (Given that the case was decided the same year that HIPAA was passed, but before the regulations were issued, we cannot be sure if it would find the same way today.).

257 Nick Nicholas, Confidentiality, Disclosure and Access to Medical Records, 9 OBSTETRICIAN \& GYNECOLOGIST 257, 260 (2007).

258 Tarisoff, 551 P.2d at 346.

$259 \mathrm{Id}$. at 347.
Comment [s17]: I would recommend paraphrasing this so that we don't have to put it in a block quote.

Comment [s18R17]: TRB: I agree the block quote is awkward looking, but the entire text really needs to be in the article and paraphrasing does not capture it well. How about what I tried here? Does that capture it well enough to delete the block quote?

Comment [s19R17]: I accidentally deleted your comment. I think it works. 
confidentiality against public safety, and public safety is paramount. But risks of non-disclosure of SF are much less imminent and severe, suggesting that the balance might tilt in favor of respecting common-law confidentiality. Indeed, at least two state courts have recognized that conducting additional analyses on an unwitting patient's tissue sample might constitute the tort of intrusion upon seclusion. 260

Physicians and laboratories should also ensure that they do not violate the federal HIPAA Privacy Rule or other state-privacy statutes. Rather than pointing to their patient's genetic mutation as the basis for the disclosure to a relative, providers could simply state that "it has come to our attention that you might be at risk for a genetic mutation, and if you would like more information, you will need to follow-up with your primary care provider." But patients may not heed this sort of vague warning, and thus, it may not prevent future harm.

Because this sort of disclosure is likely too imprecise to be helpful, providers might avail themselves of an HIPAA Privacy Rule's public-safety exception. But the "public safety" exception is not helpful because it allows disclosure of protected health information to "avert a serious threat to health or safety" such as the type of risk present in the Tarasoff case.261 A physician might disclose protected-health information if she believes, in good faith, that the disclosure is "necessary to prevent or lessen a serious and imminent threat to the health or safety of a person or the public"; and "is to a person or persons reasonably able to prevent or lessen the threat." 262 Where the risk is of imminently contracting contagious disease, courts may require physicians to breach confidentiality and warn family members that the patient is contagious. 263

But the problem is of course, with the word "imminent." Even if the genetic disease is serious and treatment is effective and available, a court will probably not allow disclosure of genetic risks under this exception. As Mark Rothstein has pointed out, "imminence" is a high bar; it "implies such immediacy that many mental health professionals might believe that even a deeply troubled and dangerous person who made credible threats did not expressly indicate that he or she was planning to take imminent action to carry out the threats."264 Though there is not much case law, disclosure is inappropriate unless the risk was of serious, imminent physical violence. 265 This HIPAA exception suggests that defendants should only breach confidentiality when the risk is an imminent one.266 Under this standard, highly-penetrant and serious genetic diseases are not imminent enough to warrant disclosure under this HIPAA exception.

260 See Doe, 748 A.2d at 340; see also, Havasupai Tribe of Havasupai Reservation v. Ariz. Bd. of Regents, 204 P.3d 1063, 1076 (Ariz. Ct. App. 2008).

26145 C.F.R. $\$ 164.512(\mathrm{j})(2002)$.

262 Id.; see also, DePt. Of HeAlth AND Human SERvices, OfFice for Civil Rights, A Health CARe PROVIDER'S GUIDE TO THE HIPAA PRIVACY RULE: COMMUNICATING WITH A PATIENT'S FAMILY, FRIENDS, OR OTHERS INVOLVED IN THE PATIENT'S CARE, 2,

https://www.hhs.gov/sites/default/files/provider ffg.pdf (last visited March 4, 2018).

263 Hofmann v. Blackmon, 241 So.2d 752, 753 (Fla. Dist. Ct. App. 1970).

264 Rothstein, supra note 105, at 107.

265 See Kuligoski v. Brattleboro Retreat, 156 A.3d 436, 458-59 (Vt. 2016), as amended for clarification on Oct. 10, 2016.

266 US DeP'T OF HEAlth \& Human SERVICES, Where THE HIPAA PRIVACy RUle APPLIES, DOES IT PERMIT A HEALTH CARE PROVIDER TO DISCLOSE PROTECTED HEALTH INFORMATION (PHI) ABOUT A PATIENT TO LAW ENFORCEMENT, FAMILY MEMBERS, OR OTHERS IF THE PROVIDER BELIEVES THE PATIENT 
Is there an alternative route for disclosure that complies with HIPAA? One possibility is not obvious, but relies on the ordinary treatment exception.267 The HIPAA privacy rule allows a covered entity to disclose PHI "for its own treatment" or "for treatment activities of a health care provider."268 But the regulations do not specify for whom the treatment must be intended.269 It might come as a surprise to many that the plain-language reading of HIPAA regulations may permit the disclosure of a proband's PHI to treat the proband's first-degree relative. 270 The disclosure cannot be merely in the form of a warning, but must be part of the relative's treatment plan.

Because laboratories would disclose an SF for treatment purposes, HIPAA may not create the anticipated hurdles to disclosure. But there is still the possibility of tort liability for publicdisclosure of private facts if the physician discloses the proband's relative of a non-imminent risk. As the only cases to require a breach of confidentiality involved specific threats of imminent physical violence, judges will not be as willing to require a breach of common-law privacy principles where the warning is limited to a potential for future genetic disease. 271

Given the family dynamics, emotions, and lack of provider-patient relationship between the laboratory and the proband's relative, it would be reasonable to consider the physician or laboratory to have discharged their tort duty once they inform the proband-or ordering physician - of the risk, with a commendation from the provider that he or she should tell their family members. If the provider informs the proband that the risk is genetic and instructs the proband to warn close family members, laboratories and providers should not breach the proband's common-law confidentiality rights and reach out to the proband's relative. The provider and the proband is better -positioned to know how to inform the relative.

Most probands do share genetic test results with first-degree relatives, so the ordering physician may presume this.272 But the likelihood of disclosing to family depends on individual variables such as gender, education, family history of cancer, and psychological feelings of selfefficacy and optimism. 273 And $10.5 \%$ of relatives who learned of their proband's genetic results

PRESENTS A SERIOUS DANGER TO SELF OR OTHERS?, https://www.hhs.gov/hipaa/for-

professionals/faq/520/does-hipaa-permit-a-health-care-provider-to-disclose-information-if-the-patient-isa-danger/index.html (last updated July 26, 2013).

26745 C.F.R. $\$ 164.506(a)(2002)$.

26845 C.F.R. $\S 164.506$ (2002).

269 See id.

27045 C.F.R. $\$ 164.506$ (a) (2002).

271 The key here would be whether the genetic risk information is considered private enough such that disclosure would be offensive or objectionable to a reasonable person. Typically the disclosure of private health information counts for this tort. See, See, Richard E. Kaye, Invasion of Privacy by Public

Disclosure of Private Facts , 103 AM. JUR. Proof of Facts FED.3RD 159 (2008).

272 Mary Daly, et al., Communicating genetic test results within the family: Is it lost in translation? A survey of relatives in the randomized six-step study, 15 FAMILY CANCER 697, 698 (2016)[hereinafter Daly] ("[O]verall, probands reported sharing their test result with $80 \%$ of 838 eligible FDRs [first degree relatives].”).

273Darquise Lafrenière, Family Communication Following BRCA1/2 Genetic Testing: A Close Look at the Process, 22 J. GenetiC COUNSELING 323, 323 (2013) ("Given the nature of modern families and 
could not remember the result later. This group was much more likely to be male.274 If the provider has reason to believe that the proband will not tell their relatives about a SF linked to highly penetrant colon cancer - perhaps because the proband is male and is not optimistic about cancer treatment - then the provider, but not the laboratory, might have an obligation to warn the proband's readily identifiable relatives based upon the "special relationship" recognized between physicians and patients. But because there is no special relationship between the laboratory and the proband, it seems hard to stretch that arms-length relationship to require that the laboratory do more than disclose SFs to the ordering physician or the proband.

Genetic-risk information is not like imminent-violence-risk information or the risk of injuring oneself. Almost anyone would welcome a warning that they are at risk of serious, imminent violence or injury. No person desires to be shot or cut. But not everyone wants to know if they are at risk of an uncertain genetic disease. Even if there is a well-tolerated treatment available, a non-trivial number of people would not want to know of this distant threat.275 Judges should not require a breach of patient confidentiality when there is not the kind of serious peril to public safety at issue in Tarasoff. 276

\section{CONCLUSION}

The Rowland factors are not dissimilar from the ACMG working group's criteria on SFs, or even from the factors insurance companies use to determine whether to cover genetic tests. 277 Each asks whether the cost is worth the benefit. The factors can determine whether, on average, imposing a duty to warn on a laboratory strikes the right balance of fairness between the defendant's need-to-pay and the plaintiff's entitlement to compensation.

Compared to the more traditional duty-to-warn cases, the case for laboratories directly warning plaintiffs of SFs is far weaker. First, laboratories have no special relationship with patients seeking WES or WGS for an unrelated disease. Second, a physician-with whom the patient does

complexity of the genetic information, some patients may consider communication difficult or impossible. Although evidence suggests that most individuals share test results with first-degree relatives soon after notification, genetic service providers are likely to encounter patients who will not notify a sizeable number of relatives for whom genetic information could have significant implications. Individuals may experience difficulty recalling and understanding information received during genetic counseling sessions, which raises concerns about the accuracy of information conveyed to at-risk relatives."); see also, Ashley Elrick, et al., Psychosocial and Clinical Factors Associated with Family Communication of Cancer Genetic Test Results among Women Diagnosed with Breast Cancer at a Young Age, 26 J. GENETIC CounSELING 173, 181 (2017).

274 Daly, supra note 276, at 699 ("Of interest, $10.5 \%$ reported that they were told the test result but were not able to remember it. Those relatives reporting that they did not remember the test result were significantly more likely to be male gender than female gender (57 vs. $43 \%, p>0.001)$.")).

275 Harvard T.H. Chan Sch. of Pub. Health, The Public and Genetic Editing, Testing, and THERAPY, 5 (2016).

276 Tarasoff v. Regents of the Univ. of Cal., 551 P.2d 334, 339 (Sup. Ct. Cal. 1976).

277 Rowland, 443 P.2d at 564, Kalia, supra note 39, at 250; Andrew Hresko \& Susanne B. Haga, Insurance Coverage Policies for Personalized Medicine, 2 J. OF PERSONALIZED MED. 208, 210 (2012);

Michael D Graf et al, Genetic Testing Insurance Coverage Trends; A Review of Publicly Available

Policies from the Largest US Payers, 10 PERSONALIZED MED. 235, 237 (2013). 
have a special relationship and for whom liability for non-disclosure is more appropriatemediates the results. Of course, it might be precisely because patients are looking to sue someone other than their physician that they file a complaint against the laboratory. When something goes wrong and the patient is injured, the laboratory provides an option to hold an entity accountable, especially when the physician, who may have also made a mistake, is a friend. But it is precisely that the laboratory is somewhat removed from the patient's direct experience that the law should not hold it accountable to the same standard as the ordering physician. While liability for failing to follow-up on an actionable SF could attach to the physician, liability for the laboratory makes much less sense.

We currently have limited information on the likelihood that a monogenic mutation will develop into disease (known as genetic penetrance and the information we have likely inflates this value for those who are currently symptom-free. Thus, presence of a genetic mutation does not present the kind of foreseeable, imminent, and serious risk giving rise to a common-law duty to warn for laboratories. Additionally, it would ask too much for courts to expect laboratories to internalize the costs of this new duty, as they are likely not insured for this risk and have no means to bill for the additional resources it would require especially to ensure accurate results are validly and correctly interpreted. The difficulty proving causation for a concrete injury also mitigates against imposing a tort duty to warn as a matter of law.278 Given the ambiguous nature of an SF from WES or WGS, it is preferable to have any SFs delivered by an ordering physician and in the context of clinical care. To impose liability on a laboratory to directly warn its patients would engage in the tempting imposition of tort obligations where harms are conceivable ex ante, but hardly reasonably foreseeable. Currently, the significant cost burden on defendants further mitigates against imposing on genetics laboratories a duty to warn patients of their secondary findings.

278 David A. Fischer, Causation in Fact in Omission Cases, 1992 UtAH L. ReV. 1335, 1343 (1992). 